\title{
DIE CHRISTOLOGIE VAN DIE JEHOVA SE GETUIES
} deur

\author{
J. H. BREYTENBACH
}

\section{INLEIDING}

\section{(A) HISTORIES.}

Die Jehova Getuies is 'n adventistiese sekte wat in Amerika sy ontstaan gehad het. Die sekte is in 1872 georganiseer teen die agtergrond van 'n verwagting van die spoedige wederkoms van Christus en die aanbreek van die millenium, die duisendjarige vrederyk - dan sou die heerskappy of koninkryk van God op aarde gevestig word.

Die stigter van die sekte was Charles Taze Russell (18521916) van New York en van huis uit 'n Presbiteriaan. Nadat hy afvallig geraak het van die geloof van sy ouers, het hy sterk onder die invloed van die adventistiese leerstellings van William Miller gekom. Deur ernstige Bybelondersoek, sonder die hulp van ander en sonder wetenskaplike agtergrond, het hy probeer te wete kom wat God se plan met die wêreld is. Deur talle geskrifte het hy dan ook die „toekomsplan” van God bekend gemaak, soos dit aan hom ,geopenbaar" is. Hy het geweldig baie geskryf en het sy leerstellings later saamgevat in ses boekdele onder titel "Studies in the Scriptures".

In 1881 het Russell ,The Watch Tower Bible and Tract Society" gestig wat sedert sy stigting miljoene boeke en tydskrifte oor die hele wêreld versprei het. Later is die „International Bible Students' Association" in die genootskap geinkorporeer. Russell het baie duidelik die mag van die geskrewe woord besef en het geen steen onaangeroerd gelaat om sy leerstellings wêreldwyd te versprei nie. Hierdie opvatting het daartoe gelei dat die Jehova Getuies vandag in New York die grootste drukpers vir godsdienstige boeke ter wêreld het. Daar verskyn byvoorbeeld halfmaandeliks 'n gemiddelde oplaag van 4,850,000 eksemplare van hulle tydskrif, „Die Wagtoring” in 70 tale van die wêreld en tussen 150 en 160 miljoen Bybels, boeke, tydskrifte, ens. word per jaar gedruk. ${ }^{1}$ ). Ook die getal arbeiders en die aantal ure wat hulle in die arbeidsveld deurbring, neem fenomenale syfers aan :-

In die jaar 1964 was daar meer as 'n miljoen aankondigers oor die wêreld wat „die ewige goeie nuus" tot „'n getuienis

1) Vgl. Die Wagtoring, 1 Augustus 1965, bls. 359. 
van al die nasies" verkondig het. In 194 lande en eilande van die see, het hulle gepreek en Bybels en Bybelliteratuur in 162 verskillende tale versprei, terwyl hulle meer as 162 miljoen uur daaraan bestee het. Hulle het sowat 55 miljoen herbesoeke by die mense gedoen, en meer as 740,000 Bybelstudies is van een tot vier keer elke maand in die huise van mense gehou. ${ }^{2}$ ).

Charles Russell wat 'n man van twyfelagtige karakter en optrede was, ${ }^{3}$ ) is by sy dood in Oktober 1916 as President van die Wagtoring Genootskap, opgevolg deur „Judge” Franklin Rutherford. Rutherford was 'n groot entoesias vir die leerstellings van Russel en hy het net soveel, indien nie nog meer as Russell nie, geskrywe en propaganda gemaak vir die sekte. Enkele van sy belangrikste boeke wat verskyn het, is bv. „Harp of God", „The Kingdom", „Jehova”, „Creation” ens. By sy afsterwe in Januarie 1942 is Rutherford opgevolg deur Nathan H. Knorr wat nog steeds aan die hoof staan van hierdie wêreldverbreide sekte.

Omdat Charles Russell by die stigting van die sekte met Bybelklasse oor die naderende duisendjarige vrederyk begin het, en daar sedertdien gereelde Bybelstudie-byeenkomste gehou is, het die Jehova Getuies oorspronklik bekend gestaan as "Internasionale Bybelstudente". Hulle is ook „Russelliete" genoem na aanleiding van hulle stigter C. T. Russell. Maar in 1931, op grond van die twyfelagtige verlede van hulle stigter, is hulle naam verander na "Jehova se Getuies" of "Getuies van Jehova”. Hierdeur wou hulle beslis die harde feite omtrent hulle stigter verbloem en aan die sekte ' $n$ meer Bybelse fundering ten grondslag lê. Jesaja 43:12 wat lui :

„Ek het verkondig en verlos en dit laat hoor, en daar was geen ander (god) onder julle nie; en julle is my getuies, spreek die Here (of vlgs. die Jehova Getuies : "sê Jehova") en Ek is God", het hierdie doel van die sekte baie goed gedien.

\section{(B) ONWETENSKEPLIKE WERKWYSE VAN DIE JEHOVA GETUIES.}

Die Jehova Getuies het tot 1950 nie 'n eie Bybelvertaling besit nie. Omdat baie van hulle leerstellings bots met tekste

2) Vgl. Die Wagtoring, 15 November 1965, bls. 515.

$\therefore$ Vgl. bv. in verband met Russell se egskeiding $H$. C. J. Flemming.

Sektedwalinge in ons Land, Bloemfontein 1941, bls. 49 en 50. 
wat in die Bybel staan, het hulle besluit om hulle eie Bybelvertaling uit te gee. In 1950 het hulle „New World Translation of the Christian Greek Scriptures" verskyn en in 1953 en 1955 hulle "New World Translation of the Hebrew Scriptures" in 5 dele. ${ }^{4}$ ) Dit is egter baie duidelik nie 'n wetenskaplik-verantwoorde vertaling van die Bybel nie, maar is alleen daarop gerig om hulle leerstellings te ondersteun. 'n Sprekende voorbeeld hiervoor is die vertaling van Joh. 1:1. ${ }^{5}$ ).

'n Verdere bewys vir hulle onwetenskaplike werkwyse is die feit dat hulle, tenspyte daarvan dat hulle 'n eie vertaling van die Bybel besit, nie net van daardie één vertaling gebruik maak wanneer hulle tekste aanhaal nie, maar van verskillende vertalings. Op die eerste bladsy van elke uitgawe van „Die Wagtoring" is dit baie duidelik dat daar benewens die „New World Translation" en die Afrikaanse Bybelvertaling nog 13 ander vertalings gebruik word bv. die "American Standard Version”, „The Emphatic Diaglott”, die „Katolieke Douay Vertaling”, ens. Hulle haal dan die vertaling aan wat hulle leerstellings die beste weergee. Daar is dus weinig sprake van enige konsekwensie of van 'n ernstige poging om die werklike betekenis van die teks op wetenskaplike wyse vas te stel.

Ook die wyse waarop die Jehova Getuies die ontstaan van die Heilige Skrif beskou, spreek baie duidelik in hierdie verband. Die Jehova Getuies hou bv. krampagtig en op onwetenskaplike wyse vas aan die teorie dat die eerste vyf boeke van die Bybel deur Moses geskryf is. Op die vraag waar Moses die kennis oor die skepping, die sondvloed, ens. gekry het, gee die Jehova Getuies die volgende antwoord -

After Adam wrote these things and died, other men wrote down things that happened after that. Just as Adam had done before them, they wrote these things on clay tablets. Men saved these tablets so that many years later they could read what was written on these tablets, and when he started to write the opening part of the Bible he copied down what these tablets said .... That is how Moses knew what to write in the first part of the Bible about creation, the flood of Noah's day and things about Abraham and Isaac and Jacob. ${ }^{6}$ ).

4) Gewoonlik aangedui met die afkorting N.W.

5) Vgl. daarvoor Hoofstuk IV, (A) Preeksistensie, bls. 29.

6) From Paradise Lost to Paradise Regained, Watch Tower Bible and Tract Society of Pennsylvania 1958, p. 65. 
Op hierdie standpunt hoef beslis geen kommentaar gelewer te word nie. Dit plaas noodwendig net 'n groot vraagteken agter die Hebreeuse kennis van die leiers van die Jehova Getuies en beslis ook agter hulle „New World Translation” van die Bybel.

Nog 'n enkele voorbeeld om die saak onder bespreking te illustreer. Die Jehova Getuies is hewig gekant teen alle vorme van geloofsbelydenisse en dogmavorming. Dit is volgens hulle die werk van die Satan waardeur hy die Kerk verlei en verslaaf aan menslike uitvindsels en menslike werk. Die voorwoord van elke uitgawe van die tydskrif „Ontwaak!” stel dit as volg :-

„Ontwaak!” ken geen bande nie. Hy erken feite, sien feite onder oë, is vry om feite te publiseer. Hy word nie deur politieke bande gebind nie; hy word nie deur oorgelewerde geloof sbelydenisse belemmer nie. ${ }^{7}$ ).

Dit is ook baie duidelik uit een van hulle boeke :-

Not content with simple Bible truths, these fallenaway religious leaders invented doctrines that taught the opposite of such truths. They borrowed doctrines from false religions and dressed them up in Christian language. ${ }^{3}$ ).

En verder :-

The falling away from the true belief also showed itself by the making of statements of belief known as creeds. There was the "Apostles' Creed", which had not been written by Jesus' apostles. There was the Nicene Creed, which was put forth by a heathen emperor, Constantine. There was the Atanasian Creed,.... Yet in all those creeds, and in other creeds like them, there were things that did not agree with Gods Word. 9).

Die onwetenskaplike werkwyse van die Jehova Getuies is baie duidelik uit die bogenoemde voorbeelde.

(C) DIE JEHOVA GETUIES AS SEKTE.

\section{(1) Definisie van 'n Sekte}

Die woord "sekte" is afkomstig van die Latynse woord "secta" en dit is weer afgelei van die werkwoord „sequi" wat beteken „volg”. (Die moontlikheid dat dit van ,se-

¡) Vgl. bls. 2 van elke uitgawe van ,Ontwaak!”

\&) From Paradise Lost to Paradise Regained, p. 164.

9) From Paradise Lost to Paradise Regained, p. 165. 
care" = sny afgelei is, word egter nie heeltemal uitgesluit nie) 'n „Secta" is dus 'n rigting, 'n party, 'n groep volgelinge wat om 'n leidende figuur vergader is.

Die Griekse woord vir "sekte" is hairesis wat afgelei is van hairein en wat beteken : om te kies, in die sin van 'n bepaalde standpunt kies ten opsigte van 'n bepaalde leer of wysgerige rigting. Hieruit kom die woord hairetikos voort en word gebruik om iemand te beskryf wat 'n bepaalde leer of denkrigting kies en daarby bly staan.

In die Nuwe Testament word die woord in 'n neutrale én 'n ongunstige betekenis gebruik. Vgl. Hand. 5:17, 26:5 en 24:5. Dit kan ook 'n baie ongunstige betekenis hê en word dan vertaal met ,,kettery". Vgl. I Kor. 11:19; 2 Petrus 2:1, Titus 3:10 en Gal. 5:20.

Dr. F. Boerwinkel kom tot die gevolgtrekking dat ons op grond van bogenoemde tekste nie net een definisie vir die begrip sekte kan gee nie, maar wel twee nl. een in neutrale sin, nóg goedkeurend, nóg afkeurend en een met ongunstige, dus veroordelende betekenis. Vir die begrip sekte in neutrale sin gee Dr. Boerwinkel dan die volgende definisie :-

Een secte is een groep mensen die (meestal als volgelingen om een leider) van die oorspronklijke groep waaruit hij voortkomt is afgescheiden, omdat hij in bepaalde onderdelen afwijk van die oorspronklijke groep. $\left.{ }^{10}\right)$.

Hierdie definisie kan beslis toegepas word op die Jehova Getuies, maar van nog groter belang is Dr. Boerwinkel se definisie van 'n sekte in afkeurende sin :-

Een secte is een groep mensen die, voornamelijk uit begeerte naar zuiwerheid en met verabsolutering van een deelwaarheid, de solidariteit met het grote geheel van de groep verbreekt, en die deze breuk met meer als smart ervaart. ${ }^{11}$ ).

Ons vestig veral die aandag op die sinsnede ,voornamelijk uit begeerte naar zuiwerheid en met verabsolutering van een deelwaarheid". Juis hierdie kenmerk is op 'n besondere wyse van toepassing op die sekte van Jehova Getuies, omdat Russell die Bybel sg. „opnuut”, sonder enige wetenskap-

10) F. Boerwinkel, Kerk en Secte, 's-Gravenhagen 1959 blz. 19.

11) F. Boerwinkel, a.w., blz. 19 en 20. 
like agtergrondskennis ondersoek het, om sodoende die plan van God met die wêreld te wete te kom en om só die „suiwere en eenvoudige Bybels waarheid" te verkondig. Verder het hy en sy sekte dieselfde weg gegaan as alle ander sektes deur 'n deelwaarheid van die Bybel te gaan verabsoluteer. Eén waarheid word oorbeklemtoon ten koste van ander waarhede en dit word verhef tot dié waarheid, terwyl al die ander daaraan ondergeskik gemaak of daardeur verdring word.

(2) Enkele karakteristieke kenmerke van die Jehova Getuies as Sekte.

Die meeste skrywers van boeke oor sektes klassifiseer die Jehova Getuies heeltemal tereg onder die adventistiese sektes, dus dié sektes wat die wederkoms van Christus oorbeklemtoon. Hierdie eensydige oorbeklemtoning is miskien omdat die Kerk nie altyddeur en genoegsaam die verwagting van sy lewende Heer se koms verkondig het nie. Tog is en bly dit ' $n$ feit dat die Jehova Getuies 'n deelwaarheid gaan verabsoluteer het, dit verhef het tot dié waarheid van die Bybel. Soos reeds vroeër vermeld, het Russell die Bybel ondersoek om die plan van God met die wêreld te wete te kom. Hy het die Bybel met 'n besliste vooropgestelde doel en vooringenome standpunt begin bestudeer. Daarvoor het 'n eensydige en onwetenskaplike siening van die boeke Daniël en Openbaringe 'n goeie uitgangspunt gebied. ,Zowel bij Miller als bij Russel vinden we berekeningen van de Wederkomst des Heren op grond van teksten uit Daniël en de Openbaringen". ${ }^{12}$ ). Russell en sy latere volgelinge het dus die res van die Bybel gaan bestudeer vanuit sy eie visie van die boeke Daniël en Openbaringe, - die hele Bybel dus eintlik gaan sien deur die bril van die boodskap van hierdie twee boeke sonder om met die karakter van die apokaliptiek deeglik rekening te hou. So het die wederkoms van Christus die bepalende faktor in die hele leer van die Jehova Getuies geword.

Maar dit is nodig om hierdie saak van die wederkoms van Christus nader te bepaal. As Christus weer kom, sal Hy die Koninkryk van God in al sy glorie en heerlikheid vir ewig vestig oor die ganse skepping. Dan sal God alles wees in almal en oor almal. Dit gaan dus om die

12) F. Boerwinkel, a.w., blz. 57. 
Koningsheerskappy van God. Maar hierdie waarheid het Russell en sy volgelinge verabsoluteer en dit dié allesbepalende in die hele Bybel gemaak. Dit is baie duidelik uit die volgende.

Sulke belangrikheid word ook daarvoor aangedui deur die feit dat die grootste leerstelling, ja die hele tema van die Bybel die Koninkryk is. Die profesieë wat onder inspirasie van God gegee is, en die gelykenisse en leringe van Christus, voer almal as hulle hooftema, „Die Koninkryk van die Hemele” aan. ${ }^{13}$ ).

En die primêre leer van die Bybel word as volg gestel :-

It is an interpretation of demon origin to hide the truth on the primary doctrine of the Bible, the Kingdom of Jehovah God by his Son Jesus Christ. ${ }^{1+}$ ).

Die hoofdoel waarvoor Jesus Christus na die aarde gekom het en sy primêre taak was dan ook ". . . to be a witness for the Kingdom of Jehova God and by it to vindicate Jehovah's name and word". ${ }^{15}$ ). Die verabsolutering van hierdie waarheid lei daartoe dat alle ander waarhede in die Bybel van ondergeskikte aard is. As Johannes die Doper sê : „Daar is die Lam van God wat die sonde van die wêreld wegneem" (Joh. 1:29 en 36), dan lewer die Jehova Getuies as volg daaroor kommentaar :

Sodoende het Johannes die ondergeskikte doel waarvoor die Seun van God na die aarde toe gekom het, getoon, naamlik, om as 'n heilige offer aan Jehova God te sterf om die sondes van gelowige mense te kanselleer en om hulle van die oordeel van die dood te bevry, . . . ${ }^{16}$ )

Met die wederkoms van Christus vind dus die vestiging van die Koninkryk van God plaas en dit beteken primêr die volgende:-

However, the coming or establishment of the Kingdom itself in power is of the greatest importance in universal history, because the Kingdom is The Theocratic

\footnotetext{
1.) Laat God Waaragtig wees, Watchtower Bible and Tract Society, Inc. International Bible Students Association, New York 1946, bls. 126 en 127.

14) „The Kingdom is at Hand", Watchtower Bible and Tract Cociety, Inc. International Bible Students Association, New York 1944, P. 180.

15) "The Kingdom is at Hand" p. 217 Cf. also p. 248.

16) Laat God Waaragtig Wees, bls. 40.
} 
Government and by means of it the Most High God Jehovah will vindicate his great and holy name. ${ }^{17}$ ).

In die leer van die Jehova Getuies vind ons dus 'n oorbeklemtoning van die wederkoms van Christus as dié gebeure wat die Koninkryk van God sal vestig en waarin dit primêr gaan om die regverdiging van Jehova se Naam wat oneer aangedoen is.

\section{(D) WERKWYSE IN HIERDIE STUDIE.}

Omdat die Naam 'n baie belangrike plek inneem in die leer van die Jehova Getuies en bepalend is vir die Christologie, is dit nodig om in Hoofstuk II eers breedvoeriger op die saak van die Naam en alles wat daarmee saamhang in te gaan, alvorens daar tot die Christologie oorgegaan kan word. Nadat daar aangetoon is in hoe ' $n$ mate die beskouing van die Naam sy gevolge het vir die Christologie, is dit ook van belang om in Hoofstuk III nog op een belangrike aspek in die leer van die Jehova Getuies te wys, naamlik hulle tydsberekening. Laasgenoemde is van wesenlike belang, omdat dit direkte gevolge het vir die wederkomsverwagting van die Jehova Getuies.

Eers dan kan die Christologie ter sprake kom wat in Hoofstuk IV gewoonweg gestel word, sonder enige kommentariëring. Om die Christologie van die Jehova Getuies werklik te verstaan, en aan te toon dat dit geen nuwe dwaling is nie, sal in Hoofstuk $\mathrm{V}$ kortliks op die agtergrond ingegaan word waarin hoofsaaklik die kettery van die Arianisme ter sprake sal kom. Hoofstuk VI bevat dan die skriftuurlike afwysing van die Christologie van die Jehova Getuies, met ander woorde die antwoord van die Kerk aan die Jehova Getuies, in die erkenning dat die Kerk die Christologie handhaaf, soos dit deur die Kerk van al die eeue geglo en bely is.

1:) „The Kingdom is at Hand", p. 306. 


\section{DIE NAAM ,JEHOVA”}

\section{(A) DIE EIENAAM VAN GOD.}

Die Jehova Getuies maak daarop aanspraak dat hulle die eintlike en oorspronklike Naam van God van die Bybel weer ontdek het. Hulle uitgangspunt word in die volgende baie duidelik uiteengesit :-

Toe Moses voor Egipte se Farao gestaan het en Gods vereistes aan hom gestel het, het Moses die naam van God wat hom gestuur het, uitgespreek. Moses het nie gesê „die Here sê so en so" nie; want Farao en die Egiptenare het hulle eie valse gode erken en aanbid as here. Selfs toe hy sy eie mense aanspreek toe hy na hulle in Egipteland teruggekeer, het Moses die naam van God genoem om die besondere Een wat hom na Egipte terugstuur aan te wys. Ons lees : „En God sê vir Moses: Ek is wat Ek is; ook sê Hy: So moet jy vir die kinders van Israel sê, Ek is (Hebreeus: Ehyeh) het my na julle gestuur. Toe sê God verder vir Moses, So moet jy vir die kinders van Israel sê, Jehova, ... het my na julle gestuur: dit is my naam vir ewig, en dit is my gedenknaam van geslag tot geslag" (Exodus 3:14, 15 A.S.V., Engels). ${ }^{1}$ ).

Die Here God se Eienaam waaronder Hy Homself geopenbaar het is dus volgens die Jehova Getuies alleen „Jehova" (jhwh). Dit is Sy eintlike, persoonlike Naam, en as sodanig is Hy die enigste draer van die Naam. Deur die openbaring van die Naam „Jehova", het God dus aan Moses bekend gemaak Wie Hy is en geld hierdie Naam as aanduiding van ,die besondere Een wat hom na Egipte terugstuur" . . . En terwl Hyself nou gesê het dat sy Naam ,Jehova" is „vir ewig” en dat dit Sy „gedenknaam van geslag tot geslag" is, mag ons volgens die Jehova Getuies geen ander Naam vir God gebruik nie. Want as ons Hom onder 'n ander Naam aanroep, bv. „Here" of „Herr”, of Kurios, ens., dan is dit nie meer Sy Eienaam nie en spreek ons in werklikheid 'n ander God aan as dié van die Bybel.

God het aan Moses meer van die diepte van die betekenis van sy naam Jehova geopenbaar . . . ., maar die Koran verberg daardie heilige naam. Allah is nie sy naam nie, want Allah beteken ,die God". Dit is wat hy is. Dit is sy titel, maar nie die naam wat hy aan homself gee wanneer

1) Laat God Waaragtig Wees, bls. 21. 
hy met Moses praat nie; „Dit is my naam vir ewig, en dit is my gedenknaam van geslag tot geslag". (Exodus 3:6-15, A.S.) ${ }^{2}$ ).

Of ons dus Afrikaans, Engels, Duits, Zoeloe, Russies, ens. praat, móét ons die naam "Jehova" gebruik, omdat dít God se Eienaam is en net Sy Naam alleen. Die Jehova Getuies redeneer as volg:-

Ons kan daar nie van af wegkom nie; as ons sy geskrewe Woord lees, kom ons teenoor die naam van God te staan. Niks word gewen deur te beweer dat die naam nie reg uitgespreek word as "Jehova" nie. Die Skrifte wat voor ons gemeenskaplike jaartelling geskrywe is, is feitlik alles in Hebreeus geskrywe, en 'n gedeelte Siries; en in daardie Skrifte kom die alfabetiese letters vir Gods naam, naamlik Jod He Waw He (jhwh of YHWH) van die eerste tot die laaste boek voor.... Die Hebreeuse Skrifte is die eerste keer in Grieks vertaal in ongeveer $285-247$ v.C.; maar 'n tyd voor dit het die Hebreërs begin om op te hou om die naam uit te spreek, uit 'n bygelowige vrees om dit ydel te gebruik. Daarom het hulle altyd as hulle lees en by die naam kom, die woord „Adonai” (Here) of „Elohim” (God) in plek daarvan uitgespreek. Toe hulle dus daardie eerste vertaling in Grieks maak wat as die Septuagint-vertaling (LXX) bekend staan, het die vertalers die Hebreeuse gewoonte gevolg en die bogenoemde plaasvervangers vir Gods naam in hulle Griekse vertaling vertaal.) ${ }^{3}$ ).

Die Jehova Getuies grond hulle standpunt verder daarop dat daar fragmente bestaan van 6 manuskripte van die Griekse Bybel wat nie die Godsnaam (jhwh) met kurios vertaal het nie. Hierdie fragmente (Aquila, Hexapla (Q 86, 88, 243mg 264) en die Cairo Papyrus Fouad 266), ${ }^{4}$ ) het die Goddelike Naam of Tetragrammaton (vierlettergrepige Naam) weergegee of deur die oud Hebreeuse letters of deur die Goddelike Naam in Grieks te transkribeer. Hierdie feit word bevestig deur 'n Christelike teoloog Paul E. Kahle, as hy sê:-

This text, like all the others assembled in the Hexapla, was adopted by Origen from the Jews. A clear proof of

2) Wat het Godsdiens vir die Mensdom Gedoen? Watchtower Bible and Tract Societv of New York. Inc. International Bible Students Association. Brooklyn N.Y., 1951. bls. 259.

3) Laat God Waaragtig Wees, bls. 21 en 22.

t) Daar is ook nog enkele fragmente onder die fragmente van Qumran 4 wat dieselfde verskynsel vertoon. 
this is to be found in the fact that in all the five columns preserved to us the divine name is regularly given as the Tetragrammaton in Hebrew square letters. Hitherto we knew only one very early text of the Septuagint in which this method of rendering the divine name was used, the Papyrus Fouad 266 containing some verses from the last chapters of Deuteronomy. ").

\section{En verder :}

We now know that the Greek Bible text as far as it was written by Jews for Jews dit not translate the Divine name by kurios, but the Tetragrammaton written with Hebrew or Greek letters was retained in such MSS. ${ }^{6}$ ).

$\mathrm{Na}$ aanleiding van bogenoemde standpunt van die Jehova Getuies, is dit nodig dat ons enkele kritiese opmerkings oor die saak sal maak :-

(i) Paul Kahle stel dit baie duidelik in sy boek, soos ook blyk uit bogenoemde aanhaling, dat hierdie gebruik om die Goddelike Naam op dié wyse weer te gee, slegs voorgekom het in manuskripte „by Jews for Jews”. Alleen waar Jode die Ou Testament vertaal het vir Jode, is die Tetragrammaton behou. Kahle kom dan ook in die 1947 uitgawe van sy boek tot die gevolgtrekking: „No fragment or MSS of the Greek Bible has preserved the Tetragrammaton." "). Met „Greek Bible" bedoel Kahle dan die Septuaginta - dit is die Alexandrynse teks soos dit deur die Christelike Kerk ontvang is deur middel van die groot of hoofletter Codices soos die Codex Alexandrinus (A), die Codex Vaticanus (B) en die Codex Sinaiticus - het konsekwent die Goddelike Naam weergee met kurios. Die outoritatiewe weergawe van die Septuaginta bevat dus nie die Tetragrammaton nie, maar wel die Griekse weergaws nl. kurios.

Verder is dit belangrik om daarop te let dat die weergawe van die Goddelike Naam deur die Tetragrammaton in die genoemde fragmente, sonder vokale voorkom. Die Jehova Getuies kan hulle dus in werklikheid ook nie op die gebruik in hierdie fragmente beroep nie, omdat die letterlike Naam ,Jehova" daar nie voorkom nie, maar alleen die medeklinkers van die Tetragrammaton nl. (jhwh.)

(ii) Bogenoemde aanhaling uit die boek „Laat God Waaragtig

5) Paul F. Kahle. The Cairo Geniza, Oxford 1959, p. 162.

i) Paul F. Kahle, 1.c., p. 222.

i) Paul E. Kahle, The Cairo Geniza, Oxford 1947, p. 172. 
Wees", maak geen melding van die invoering van klinkertekens vir die Hebreeuse taal deur die Masorete (= oorleweraars, van masora oorlewering) nie. Die oud-Hebreeuse alfabet het $\mathrm{nl}$. geen klinkertekens gehad nie. Daar is wel van vier medeklinkers gebruik gemaak om die klinkers aan te dui. Gevolglik was die hele Ou Testament oorspronklik sonder klinkertekens geskrywe. In die na-Christelike tyd toe die algemene spreektaal hoofsaaklik Aramees was, het die gevaar baie groot geword dat die oorspronklike uitspraak van die Hebreeus in die Ou Testament verlore sou gaan. Daarom het hierdie Joodse geleerdes vanaf die 6de eeu tot \pm die 9 de eeu n.C., ${ }^{s}$ ) hulle beywer om deur middel van die klinkertekens die korrekte teks en uitspraak van die Ou Testament oor te lewer. Met betrekking tot die Godsnaam, beteken dit dat die Naam ,Jehova”, soos dit letterlik geskrywe staan in die Hebreeuse Bybel, eers in die tydperk tussen die $6 \mathrm{de}$ eeu en die 9de eeu n.C. ontstaan ht, dus $\pm 1,800-2,000$ jaar nadat God sy Naam aan Moses geopenbaar het.

(iii) Die korrekte Naam is dus nie Jehova nie, maar waarskynlik Jahwe (jhwh). Dit is baie duidelik en op wetenskaplike wyse aangetoon deur Ludwig Koehler ${ }^{9}$ ). Die naam Jehova het dus ontstaan deurdat die Jode uit godsdienstige skroom nie die Naam Jahwe uitgespreek het nie, maar in plaas daarvan die Naam Adonai (my Heer, my Soewerein) gebruik het. Die Masorete het dan ook die klinkertekens van Adonai geplaas by die medeklinkers van die Godsnaam Jahwe (met verandering van a tot $\mathbf{e}$ ). Dit was dus deur onkunde van die Christene dat die verkeerde opvatting van die naam as ,Jehova" vanaf \pm 1100 n.C. voorgekom het. ${ }^{10}$ ).

(iv) Dit word oor die algemeen aanvaar dat die skrywers van die Nuwe Testament gebruik gemaak het van die Septuaginta, die Griekse vertaling van die Ou Testament. Maar dit kon beslis nie as algemene reël en as volkome vasstaande beskou word nie. Weens die feit dat die skrywers nie altyd die letterlike woorde aangehaal het nie, maar dikwels met wysiginge of weglatings, is dit onmoontlik om met alle sekerheid vas te stel dat almal

*) Dit is die datering van B. Gemser. Hebreense Spraakkı's. Pretoria 1953, bls. 13. Paul E. Kahle. The Cairo Geniza, gee 'n later datering.

9) Vgl. Koehler - Baumgartner. Lexicon in Veteris Testamenti Libros, Leiden 1958, S. 369.

1') Vgl. Koehler - Baumgartner, a.a.o., S.369. 
wel die Septuaginta gebruik het. So het bv. die skrywer van die boek Openbaringe waarskynlik nie die Septuaginta gebruik nie. Die skrywers wat dus nie uit die Septuaginta aangehaal het nie, het waarskynlik 'n Hebreeuse manuskrip gebruik en het dus self die Godsnaam Jahwe weergegee met kurios, sonder die slaafse navolging van die Septuaginta.

(v) Die Nuwe Testamentiese skrywers het die Godsnaam weergegee met kurios. Al het hulle dit gedoen op die voorbeeld van die Septuaginta, dan bly die feit nog staan dät hulle dit gedoen het - dát hulle dit dus nie as dwaling beskou het nie. En hulle was die getuies van die Gekruisigde en Opgestane Heer - wié is óns dan om dit te betwyfel of selfs te verander?

(vi) Enkele voorbeelde uit die Nuwe Testament waar kurios gebruik is as vertaling van die Ou Testamentiese Godsnaam Jahwe :-

(a) Hebreērs 8:11: „En hulle sal nie meer elkeen sy naaste en elkeen sy broer leer en sê : Ken die Here nie; want almal sal My ken, klein en groot onder hulle". Dit is 'n aanhaling uit Jeremia 31:34. Baie duidelik word 'et-jhwe hier vertaal met ton kurion.

(b) Handelinge 4:26: „Die konings van die aarde het saamgestaan en die owerstes het saamvergader teen die Here en teen sy Gesalfde". Psalm 2:2 word hier aangehaal. Weereens word dit vertaal met kurios.

(c) Dan is daar nog talle voorbeelde waar die Hebreeuse kô 'āmar jhwh of ne'ûm jhwh vertaal word met legei kurios. Vgl. bv. Hand. 7:49 met Jes. 66:1; Hebr. 8:8,9 en 10 met Jer. $31: 31,32$ en 33 , ens. (Vgl. verder ook Hebr. 7:21 met Psalm 110:4; Hebr. 12:5 en 6 met Spreuke 3:11 en 12; Openb. 4:8 met Jes. 6:3; Matt. 22:37 met Deut. 6:5 ens.).

(d) Opmerklik is dat die Godsnaam in die meeste gevalle weergee word as kurios, sonder die lidwoord. Dit het dus eintlik geword tot eienaam van God, netsoos Jahwe die eienaam in Hebreeus is.

G. Quell stel dit asvolg :

Jedenfalls ist bei artikellosen kurios der Charakter des hebräischen Grundwortes als Eigenname deutlicher gewahrt als in der Determination ho kurios, die wie euergetēs oder sótër einfach eine appella- 
tivische Würdebezeichung darstelt. "

(vii) Ten opsigte van die Naam as sodanig, nog 'n enkele opmerking : Gotfried Quell kom in sy ondersoek na die Naam van God in die Ou Testament onder ander tot die volgende konklusies :-

Aus diesem wechselnden Befund ergibt sich, dass die Vokalisation sicher weder in diesem noch in jenem Fall dem Wort gerecht wird, sondern stets ein umschreibendes Qerē bedeutet. jehówâ soll als 'adonāi „Allherr”, jéhówî als 'élóhìm „Gott”, jehawâ als semā ",der Name" gelesen werden, während der Eigenname Gottes selbst aus Lesung und Meditation verschwinden soll. ${ }^{12}$ ).

En verder ook :

Der Befund lehrt, dass schlechterdings nicht mehr einwandfrei festzustellen ist, was Jhwh heisst. Alle Versuche der etymologischen Deutung, die ja immer auch zugleich der Frömmigkeitsgehalt des Wortes ermitteln möchten und unter dem Einfluss bestimmter Theorien hieruiber stehen, leiden unter der Vieldeutigkeit. Am meisten erschwerend wirkt nach dieser Richtung jener Zaun, den die biblische Uberlieferung um den Gottesname gezogen hat, weil ihr die Gefahren, die in der Tatsache eines Eigennames der Gottheit beschlossen sind, gegenwartig waren. Das lag teils an einer Tabu-Empfindung, teils - und dass darf nicht ganz übersehen werden - an reifer Erkenntuis des Wesens der Gottheit. ${ }^{13}$ ).

\section{(B) SENTRALE UITGANGSPUNT: JESAJA $42: 8$.}

Die saak wat in Jes. 42:8 na vore kom, hang baie nou saam met die voorafgaande. Die Jehova Getuies vertaal Jes. 42:8 as volg : „Ek is Jehova, dit is my naam; en my eer sal Ek aan geen ander gee, of ook my lof aan gesnede beelde". (A.S.V. Engels) ${ }^{14}$ ) Vergelyk ook Jesaja 48:11. Dit gaan dus om die Naam van Jehova en om Sy enigheid. Die kernwoord is hier kābôd wat volgens Jehova Getuies beteken : eer heerlikheid, glorie.

Jehova God sal Sy kābôd, Sy eer aan geen ander gee nie.

11) Gerhard Kittel. a.a.O., S. 1057.

12) Gerhard Kittel, a.a.O., S. 1066.

1.3) Gerhard Kittel, a.a.O., S. 1067-1068.

14) A.S.V. is die afkorting vir die "American Standard Version". 
Hy is dus die alleenbesitter van die kābôd, Hy is alléén Gód. „Ek is Jehova, en daar is geen ander nie; buiten My is daar geen God nie; . . ." (Jes. 45:5 vgl. ook vers 6, 14 en 18). „Hoor, O Israel : Jehova onse God is een Jehova!" (A.S.V.) Jehova is dus die enige waaragtige God. Hy is van ewigheid af en $\mathrm{Hy}$,regeer vir ewig oor die hele ruimte van die heelal ... D Daar Hy ewig en onsterflik is, is $\mathrm{Hy}$, in hierdie sin, die enigste Wese." ${ }^{1-}$ ) Omdat Jehova alleen God is en alleen heerlikheid besit en Hy die enigste is aan wie heerlikheid en eer gebring moet word, kan daar niks of niemand anders wees wat heerlikheid besit of aan wie eer en heerlikheid toekom nie.

Bogenoemde redenering het baie belangrike konsekwensies met betrekking tot die Christologie van die Jehova Getuies. Want as Jehova die enigste ware God is wat Sy heerlikheid of eer aan niemand gee nie, beteken dit volgens die Jehova Getuies dat ook Sy Seun, Jesus Christus, daar geen deel aan het nie. Die Seun kan daarom die heerlikheid of eer van die Vader nie met Hom deel nie en kan dus ook nie waaragtig Gód wees nie. Hy het alleen deel aan die goddelike sfeer; Hy kan hoogstens goddelik of 'n god wees.

Op dié wyse handhaaf die Jehova Getuies die enigheid van God, terwyl hulle die Godheid van Christus en so ook van die Heilige Gees opoffer. ${ }^{16}$ ) Maar in Hoofstuk VI sal daar aangetoon word dat Christus wel deel het aan die doxa van God en dus Self ook werklik en waaragtig Gód is.

\section{(C) SY NAAM ONEER AANGEDOEN.}

Voor die skepping van die aarde en die mense, het Jehova God al sy heilige, geestesskepsele in die hemel in 'n ordelike, harmonieuse, vredevolle organisasie onder Homself opgestel om Sy wil te volbring. Al hierdie engele - geestesskepsele het sy universele organisasie wat daarbo is, uitgemaak, - dit was die "vrou" van Jehova God. Toe die volmaakte mensepaar geskap is en in die tuin van Eden geplaas is om God se opdragte uit te voer, was hulle die sigbare deel van Jehova se universele organisasie. Hierdie sigbare, aardse organisasie was 'n teokrasie gewees, omdat Jehova God deur middel van 'n deel van sy hemelse organisasie die aardse organisasie bestuur en geregeer het.

Satan, die duiwel, was oorspronklik deel van hierdie uni-

15) Laat God Wraragtig Wees, bls. 25 .

16) Die Goddelike Drieënheid word as onlogies en anti-redelik beskou. Hulle stel dit grafies só voor: $3 \times 1=1$ en dit is tog belaglik (vlgs. hulle). 
versele organisasie, as 'n geestelike seun van God met die naam van Lucifer. 'n Pos van groot vertroue en verantwoordelikheid is aan hom opgedra. Hy was die hoof van dié deel van Jehova se organisasie wat die sigbare deel moes regeer. Hy was dus opperheer van die mensdom.

God het die volmaakte mensepaar in die tuin van Eden geplaas, en dit was die gees Lucifer se plig om hulle te help om aan Gods vereistes te voldoen en om hulle op te voed in hulle behoorlike verhouding teenoor hulle Skepper. ${ }^{17}$ ).

Vir 'n tyd lank was daar volmaakte vrede in die ganse heelal gewees, maar dit het nie voortgeduur nie. Hebsug en begerigheid het veroorsaak dat Lucifer die toewyding en aanbidding wat aan Jehova alleen toegekom het, vir homself begeer het. Lucifer het dus eintlik gegryp na die heerlikheid wat alleen God se deel is en wat Hy aan geen ander gee nie (Vgl. Jes. 14:12-14). Hy wou soos God wees.

Lucifer became highminded and set out to exalt himself higher than God's appointment. This he attempted to do by trying to turn that righteous world from a Theocratic world into a world of his own, subject to himself as the god to be adored and as a ruler independent of the Universal Theocrat, Jehovah God. ${ }^{18}$ ).

Die Satan het hierdie voorneme ten uitvoer gebring deur Adam en Eva te verlei en later ook vele van die geesteskepsele van Jehova se universele organisasie. Op dié wyse is die Teokrasie tot niet gemaak en het die mensdom die sigbare deel van Satan se organisasie geword. Die geestesskepsele wat hom gevolg het, het demone geword en het die hemelse deel van sy organisasie gevorm. Deur hierdie rebellie in die hemel en op die aarde is die universele heerskappy van Jehova God, die groot Teokraat en universele Soewerein ontken en is Sy Naam oneer aangedoen. Die hele verdere verloop van die geskiedenis word dan gesien in die lig daarvan dat Jehova se Naam oneer aangedoen is en dat Hy Sy Naam sal regverdig.

Satan het as straf sy posisie in die hemelse organisasie van Jehova verloor en is deur Jehova vervloek en tot die dood veroordeel. Hoewel hy nog die opperheer van die mensdom gebly het, sou hy op Jehova se bestemde tyd verniet word :-

Also, God did not purpose himself to execute the treacher-

ii) Laat die God Waaragtig Wees, bls. 46.

1x) "The Kingdom is at Hand", p. 57. 
ous Serpent, but to use his Son, the offspring of his "woman" or holy organization. This Son or Seed of God's "woman" would have such hatred of iniquity and all workers of iniquity that he would never compromise, but would destroy completely that old Serpent, Satan the Devil. ${ }^{19}$ ).

Tot op daardie tyd sal daar voortdurende haat en vyandskap wees tussen Jehova se organisasie en die organisasie van die Satan.

Hierdie vyandskap is duidelik uit die optrede van Kain wat sy broer Abel doodgeslaan het. Satan het ook gebruik gemaak van die nageslag van Gam, die seun van Noag. Die duiwel se aardse organisasie is egter uitgewis met die sondvloed. Maar hy het spoedig weer sy aardse organisasie herstel deur middel van Nimrod, die kleinseun van Gam. Nimrod het nl. die heerskappy van Jehova verontagsaam en 'n wêreldheerskappy gevestig, deur homself koning te maak en sy onderdane te verplig om hom en sy staat te aanbid, in plaas van Jehova. By Babel, die sentrum van Nimrod se koninkryk, is ook die toring van Babel later gebou met die doel om die mense te verenig rondom 'n gesentraliseerde wêreldregering. Babel het dan ook eintlik die sentrum gevorm van die georganiseerde opstand teen die universele regering van Jehova God.

It is Babel, or Babylon, that is used throughout the Holy Scriptures to simbolize the organization of Satan the Devil. Fittingly, therefore, Babylon is pictured as an unclean woman, Satan's woman or wife, the mother of his seed Genesis 11:1-9. Babylon on earth became the nursing place of organized religion, which is demonism or demonolatry. All of Babylon's kings, from Nimrod on practiced religion or devil-worship. ${ }^{20}$ ).

Die Satan het ook van georganiseerde valse religie of godsdiens gebruik gemaak om die mense te verlei. Dit is reeds duidelik uit bogenoemde aanhaling. Satan het die valse godsdiens reeds in Eden ingevoer en veral in die dae van Enos, die seun van Set, het die valse godsdiens onder die mense geweldig uitgebrei. Maar dit was veral Babilon wat die sentrum en setel van die sataniese, valse godsdiens geword het. Die valse godsdiens bestaan in die aanroeping en aanbidding van demone wat

19) "The Kingdom is at Hand", p. 60.

20) „The Kingdom is at Hand", p. 74 . 
valse gode is en die valse godsdiens word deur Satan gebruik om die mense weg te keer van die ware aanbidding van Jehova, die enige ware God.

Babilon het egter nie net simbool geword van die ganse organisasie van die Satan en van alle valse godsdiens nie, maar dit het vir die Jehova Getuies ook geword tot simbool van die godsdiens van die Christendom veral van die Rooms Katolieke Kerk wat deur hulle gebrandmerk word as die groot valse godsdiens, as Babilon die groot hoer :

Religion is the adultress and idolatress that befriends and commits religious fornication with the political and commercial elements. She is the lover of this world and blesses the world from the balcony of the Vatican and in the pulpits. Religion, whose most powerful representative has ruled from Rome for sixteen centuries, traces her origin all the way back to Babylon of Nimrod's founding, and organized religion deservedly bears the name „Babylon!" ${ }^{21}$ ).

En van die geestelikes van die Christenheid sê hulle :-

Hierdie persone sal geskok wees as daar vir hulle gesê word dat hulle in slawerny, slawerny aan 'n god, en bowendien 'n valse god, verkeer, maar hulle verkeer wel daarin, want die Bybelse reël is dat 'n mens die dienskneg is van die een wat jy dien (Rom. 6:16). Hulle onderwerp hulleself, hoewel onwetend, aan Satan die Duiwel, wat in die Bybel ,die god van hierdie wêreld" genoem word. (2 Kor. $4: 4) .{ }^{22}$ ).

Die Christenheid - en dan nie net die Rooms Katolieke Kerk nie, maar al die Kerke van die offisiële Christendom is dus volgens die Jehova Getuies deel van die duiwelse organisasie van die Satan.

Satan het ook dwarsdeur die geskiedenis van die volk Israel, wat God se teokratiese volk was, probeer om Jehova se paradysbelofte aangaande die Saad van Sy „vrou" tot niet te maak. ${ }^{23}$ ). Dit het hy veral gedoen deur die koning van Israel en die volk self te verlei tot afgodsdiens :-

This was but the effort of Jehovah's great adversary to show

21) ..The Kingdom is at Hand", p. 345 and 346.

22) Die Wagtoring, 1 Augustus 1965 bls. 354.

2:1) Die vrou aan wie die belofte gemaak is, was volgens die Jehova Getuies nie die ongehoorsame Eva nie, maar was Jehova se „vrou", Sy hemelse organisasie van getroue geestesskepsele! Vgl. „From Paradise Lost to Paradise Regained", bls. 34. 
that Almighty God could not set up a government upon this earth but that the Devil could corrupt it beyond God's use. It was part of the Devil's scheme to bring worldwide reproach upon Jehovah's name. It was Satan's defiance to Jehovah's universal domination. ${ }^{2-4}$ ).

Maar dit was veral teen Jesus Christus, die beloofde Saad Self, dat die Satan met al sy mag gestry het. Al sy pogings soos bv. kindermoord van Bethlehem deur Herodes, die versosking in die woestyn, al die ander versoekinge en teenstand, ens., was bedoel om die Saad skadeloos te stel en die Naam van Jehova God nog meer oneer aan te doen:-

The Seed of the Serpent continually trailed the steps of God's anointed King, Christ Jesus, the foretold Seed of the "woman". At Eden Jehovah God had said that the Serpent should bruise the heel of the woman's Seed. So the Serpent and his seed hissed out enmity against him. They bared their fangs ready to squirt the venom of death through them and into their victim. ${ }^{25}$ ).

So het die Satan van die begin af die voornemens van Jehova probeer dwarsboom en Sy Naam oneer aangedoen. Maar hy kon niks uitrig as om die Saad in die haksteen te byt nie, terwyl die Saad Self die kop van die ou slang, die Satan, sal verbrysel. Dia finale vernietiging van die Satan se hele organisasie sal in die slag van Armageddon plaasvind wat in die nabye toekoms lê.

(D) DIE REGVERDIGING VAN JEHOVA SE NAAM.

Die Jehova Getuies verklaar die Naam „Jehova” asvolg :-

Die naam „Jehova” is 'n Hebreeuse werkwoord en beteken letterlik „Hy laat dit wees”, dit wil sê vir 'n doel ... Dus staan sy naam „Jehova”, afgesien van die letterlike betekenis daarvan, vir sy voorneme in verband met sy skepsels. (Exodus 3:15-21; 6:2-8; A.S.V. Engels). Baie keer verklaar Jehova deur die hele Bybel sy voorneme om te maak dat alle nasies sowel as sy eie begunstigde volk sal weet dat Hy Jehova is .... Daarom is 'n belangrike deel van sy groot voorneme die regverdiging van sy naam wat smaad aangedoen en verkeerd voorgestel is. Sy regverdiging is belangriker as die redding van mense. ${ }^{26}$ ).

21) "The Kingdom is at Hand", p. 165.

25) "The Kingdom is at Hand", p. 230.

24i) Laat God Waaragtig Wees, bls. 30 . 
In hulle tydskrif „Ontwaak!” van 8 November 1965 word daar gestel dat die Bybel één tema in hooftrekke beskrywe en dat hierdie tema die groot voorneme van Jehova op die voorgrond stel. Hierdie tema behels dan ,.... die heiliging van Jehova se naam deur middel van Koninkryksaad. ${ }^{2 i}$ )

Omdat Jehova se Naam oneer aangedoen is en teen sy universele heerskappy geweld gepleeg is, is dit Sy voorneme om Sy naam in ere te herstel deur Sy universele Koningsheerskappy weer te vestig. Die eerste tekens daarvan is reeds sigbaar in die Koninkryksbelofte van Genesis 3, waar belowe word dat die Saad van die „vrou" die kop van die slang sal vermorsel :-

Jehovah's declaration of purpose was a covenant toward his „woman" or faithful organization. It was in fact a Kingdom covenant, because the Chief One, who is primarily The Seed, would be the King or Theocratic Governor in the "kingdom of heaven". This royal feature of the covenant become more plain and evident in the days of Jehovah's dealings with Abraham. ${ }^{28}$ ).

Hoewel die Satan die eerste mensepaar verlei het en vir hom 'n aardse organisasie gevestig het, was daar tog van tyd tot tyd mense wat hulleself aan Jehova God se kant geskaar het en die ware godsdiens beoefen het. ${ }^{29}$ ).

Hulle het die sigbare deel van Jehova se universele organisasie gevorm. Voorbeelde van sulke mense is bv. Abel, Noag en sy gesin, Abraham, Moses, Josua, die Rigters, enkele van die konings van Israel, die profete soos Elia, ens. Maar dit was veral die volk Israel wat deur die verbondsuiting by Sinaĩ tot 'n teokratiese nasie geword het. Hulle het 'n tipiese Teokrasie gevorm met 'n profetiese voorafskaduwing was van die teokratiese Regering wat Jehova van plan was om op te rig tot seën van al die nasies.

In die uitwerking van Jehova se voornemens het $\mathrm{Hy}$ die kinders van Israel tot 'n spesiale, heilige, uitverkore nasie georganiseer. Hy het dit om 'n spesiale rede gedoen, naamlik om sy groot naam ontwil ... Hierdie volk wat tot 'n nasie met Jehova as hulle God en Soewereine Re-

\footnotetext{
27) ..Ontwaak!" 8 November 1965, bls. 5 en 6 .

28) ..The Kingdom is at Hand", p. 61 .

29) Die woord wat gebruik word om hierdie saak aan te dui en wat baie dikwels voorkom is: „onkreukbaarheid". Bogenoemde manne het dus hulle integriteit teenoor Jehova bewys deur die Satan nie te gehoorsaam nie.
} 
geerder georganiseer is, het 'n tipiese Teokratiese regering gehad. ${ }^{30}$ ).

Hierdie teokratiese nasie wat 'n uitsonderingsposisie beklee het onder al die nasies, moes dus dien tot regverdiging van die Naam van Jehova deur Hom alleen te gehoorsaam en te dien. Maar omdat die volk nie daarin geslaag het nie, het Jehova God hulle in ballingskap laat wegvoer.

Verder was daar enkele groot gebeurtenisse in die loop van die geskiedenis gewees waardeur Jehova God Sy Naam geregverdig het. Die eerste een en waarskynlik ook die belangrikste was die sondvloed in die dae van Noag. Deur hierdie groot daad van Jehova is Satan se hele aardse organisasie uitgewis en het alleen die regverdige Noag en sy gesin oorgebly. Die gevolge van hierdie gebeure was: „For a time Jehovah's name was great in the earth by reason of the flood, and his power was feared". ${ }^{31}$ ). Maar die sondvloed was in werklikheid ' $n$ profetiese afbeelding van die totale vernietiging van Satan met sy sigbare en onsigbare organisasie in die nabye toekoms deur Jehova God, wanneer die finale regverdiging van Sy Naam sal plaasivnd.

So was daar ook nog die taalverwarring by die toring van Babel, die vernietiging van Sodom en Gomorra, die uittog van die Israeliete uit Egipteland en veral die terugkeer van die Jode uit die Babiloniese ballingskap. Oor die regverdiging van Jehova se Naam ten opsigte van laasgenoemde stel die Jehova Getuies dit asvolg :-

Die woord en naam van Jehova was op die spel. Dit sou nie bloot 'n oorlog net tussen Jehovah en Babilon, net terwille van sy volk Israel wees nie. Dit was 'n oorlog tussen gode. Jehova sou sy oppermag toon oor hierdie afgode, wat geen gode was nie en hulle tot stof oneer en neerlaag afbring. Dit sou 'n verpletterende neerlaag vir Satan en sy goddelose demone wees, 'n voorsmaak van die neerlaag en vernietiging van hierdie teenstanders van God en die volkome regverdiging van Jehova teen al die gode van al die nasies. ${ }^{32}$ ).

Maar die eintlike Een deur wie Jehova Sy Naam sou regverdig, is die beloofde Saad van Jehova se „vrou" of universele

30) Laat God Waaragtig Wees, bls. 198 en 199.

:1) „The Kingdom is at Hand", p. 71.

?2) Die Wagtoring, 1 Junie 1965, bls. 264. 
organisasie. Hierdie Saad van die „vrou” is dieselfde een as die Saad van die belofte wat aan Abraham gegee is en wat in die persoon van Jesus Christus op Jehova se bestemde tyd verskyn het. Soos reeds vroeër vermeld was Jesus se primêre taak op aarde - volgens die Jehova Getuies - om 'n getuie te wees van Jehova se Koninkryk en om sodoende Sy Naam te regverdig. Dieselfde opvatting spreek ook duidelik uit die volgende :-

Die regverdiging van sy Vader se naam en soəwereiniteit is sy grootste vreugde $\ldots . .{ }^{33}$ ).

Jesus het dus deur sy absolute gehoorsaamheid en deur verkondiging van die Koninkryk van Jehova sy Vader se Naam geregverdig. Maar sy lewe op aarde was eintlik alleen van belang in soverre as wat $\mathrm{Hy}$ gedurende daardie tyd bewys gelewer het dat Hy die koningskap in Jehova se universele organisasie of Koninkryk waardig is. Sy eintlike taak het nog in die toekoms gelê.

The Seed of God's ,woman" never will depart wickedly from under Jehovah's universal domination, but will fight for it and destroy all rebels against it. Thereby the Seed, who receives the „kingdom of heaven", will vindicate the word and name of Jehovah God, which name and word the old Serpent, Satan the Devil, has brought under reproach. ${ }^{34}$ )

In die jaar $1914,{ }^{35}$ ) is Satan uit die hemel verwerp met die troonbestryging van Christus en die vestiging van die Koninkryk van Jehova. Sodoende is Satan se universele regering hom ontneem en lê die finale vernietiging van sy sigbare en onsigbare organisasie in die nabye toekoms, met die oorlog van Armageddon. Hierdie oorlog sal geskied tot die regverdiging van Jehova se Naam. Uiteindelik sal die finale regverdiging van Sy Naam en die volkome herstel van Sy universele heerskappy plaasvind as die Satan self finaal vernietig word. ${ }^{36}$ ).

In die teenwoordige tyd tot met die slag van Armageddon gebruik Jehova God Sy getuies om die boodskap van die Koninkryk aan te kondig. Hulle is die enigste ware Kerk, omdat hulle deur Jehova uit die wêreld geroep is tot Sy Getuies. En as ware

\%) Laat God Waaragtig Wees. bls. 195.

34).The Kingdom is at Hand", p. 62 .

5) Vgl. vir die vasstelling van die datum 1914 Hoofstuk III. Enkele opmerkings oor die rol van die tydsberekenings in die leer van die Jehova Getuies.

36) Vgl. vir meer volledige uiteensetting Hoofstuk IV, (C), (3) Wederkoms. 
Kerk van Jehova word hulle deur Hom gebruik tot regverdiging van Sy Naam. Deur aan Hom absolute gehoorsaamheid te bewys en Hom alleen te dien, onderhou hulle die ware godsdiens en eer hulle Sy naam soos dit hoort.

Uit die voorafgaande uiteensetting is dit baie duidelik waar dit éíntlik om gaan in die leer van die Jehova Getuies. Die wederkoms van Christus en nou daarmee verbonde die regverdiging van Jehova se Naam, deur die vestiging van Sy Koninkryk, is vir die Jehova Getuies die allesbepalende. Die eintlike heilsgebeure word verplaas na die toekoms.

Die noodwendige gevolg is dat die kruisgebeure en alles wat daarmee saamhang, ook in die lig van die toekomsgebeure gesien word, - dus eintlik van hulle volle krag en sterkte ontneem word.

The name „Jesus" corresponds very closely with "Elisha" .... in that it means "Jehovah is salvation". The work of Elisha in the days of the typical kingdom of Israel, and the work of John the Baptist and of Jesus and his disciples in the days of the presence of God's anointed King, both foreshadowed a greater work to be done in connection with the establishment of Jehovah's kingdom. ${ }^{3 i}$ ).

Van die Evangelie, die blye boodskap van die feitlike verlossing uit sonde en die oorwinning oor Satan en alle bose magte, kom in die leer van die Jehova Getuies gevolglik baie min tereg. (Vgl. Hebr. 2:14; 2 Tim. 1:10; I Joh. 3:8; ens.) Die heils feite word verduister deur die ongegronde verskuiwing van die klem na die toekomsgebeure. Die gevolg is dan ook dat die Christologie in die leer van die Jehova Getuies 'n ondergeskikte plek inneem. Die leer oor Christus is volkome gekleurd en word oorheers deur die leerstelling van die vestiging van die Koninkryk van Jehova en die regverdiging van Sy Naam. Die Christologie is dan in werklikheid ook net van belang in soverre as wat dit hierdie verabsoluteerde waarheid kan dien. Met so 'n sterk klem op die enigheid van Jehova en op die regverdiging van Sy Naam, kan dit ons dus nie verbaas dat die Godheid van Christus geloën word nie, en dat Hy hoogstens goddelik kan wees en net ' $n$ instrument in Jehova se hand om Sy Naam te regverdig. ${ }^{38}$ ).

37) ..The Kingdom is at Hand", p. 309

:is) Dieselfde saak van die regverdiging van Jehova se naam spreek ook baie duidelik uit die titel van die dikwels aangehaalde werk .. Laat God Waaragtig Wees". 


\section{ENKELE OPMERKINGS OOR DIE ROL VAN DIE TYDSBEREKENING IN DIE LEER VAN DIE JEHOVA GETUIES}

Die tydsberekening speel 'n baie belangrike rol in die leer van die Jehova Getuies. Hierdie vasstelling van die datum van 'n belangrike gebeurtenis in die toekoms bv. die wederkoms van Christus is ' $n$ algemene kenmerk van die adventistiese sektes. Deur allerlei berekeninge met gebruikmaking van Bybelse gegewens word daar aan 'n bepaalde datum vasgestel waarop 'n sekere gebeurtenis sal plaasvind.

'n Baie duidelike voorbeeld van hierdie aprioriese gebruik van die Bybel is die vasstelling van die jaar 1914 deur Russell, as dié jaar waarin Christus weer sou kom. Toe dit egter nie gebeur het nie en in plaas daarvan die lste Wêreldoorlog uitgebreek het, is dit só verklaar dat Christus in 1914 die heerskappy in die hemel oorgeneem het — dus onsigbaar gekom het. Hierdie standpunt word nog steeds deur die Jehova Getuies gehandhaaf. In die uiteensetting van hulle redenasie, doen ons goed om die Jehovah Getuies self aan die woord te stel, deur middel van aanhalings uit een van hulle boeke wat in 1958 verskyn het :-

Why did the witnesses say that God's heavenly kingdom would begin in 1914? Because the "times of the Gentiles" were due to end that year. The word "Gentiles" really means "nations", that is nations that are not Jehovah's people. The New World Translation of the Bible calls the "times of the Gentiles" the "appointed times of the nations". The witnesses explained what the "times of the Gentiles" or the "appointed times of the nations" meant. They showed that it was a time period.

The Son of God told us about this time period at Luke $21: 24$. He said: "Jerusalem will be trampled on by the nations, until the appointed times of the nations are fulfilled". What would happen when the "appointed times of the nations" were ended?

Did Jesus mean that God would bring back his kingdom to Jerusalem on earth? No, Jesus meant that God's kingdom, which long ago had a king at Jerusalem, could not be set up until the end of the ,appointed times of the nations". When those "appointed times" ended, then God's kingdom would be set up with its King in heaven, where no Gentiles or ungodly nations could trample upon it .... 
The witnesses of Jehovah explained that the "appointed times of the nations" are a special kind of time period. It is the long time period when the Gentile nations or the non-Jewish nations rule the earth. It is a time when Jehovah God does not rule toward the earth. It is a time when the Devil rules the world without God's hindering the Devil ....

When did the "appointed times of the nations" begin? They began when God's kingdom on earth came to end. His kingdom ended when the last king of the nation of Israel was taken off "Jehovah's throne" at Jerusalem. (I Chronicles 29:23). The Bible uses the term "Jehovah's throne" because Israel was then God's nation and the human king ruled for Jehovah.

God's earthly nation or kingdom ended when a pagan king destroyed Jerusalem ... . No longer did Jehovah have a kingdom on the earth.

The King of Babylon took Zedekiah off "Jehovah's throne" in the years 607 B.C. and laid his city and territory desolate. So that year God's earthly kingdom ended. And that year, 607 B.C., the "appointed times of the nations" began .....

Of course we want to know when the "appointed times of the nations" ended. But first we must know how long those times are. The Bible tells us that the "appointed times of the nations" would be "seven times". Not until "seven times" had passed could Gods Kingdom begin Dani:1 4:16 A.S.

How long are "seven times"? The witnesses of Jehovah explained this by pointing to Revelation $12: 6,14$. Verse 14 (A.V.) speaks of "a time, and times, and half a time". This means three and a half times, or the half of seven times. Verse 6 speaks of three and a half times as being 1,260 days. So "seven times" would be twice 1,260 days, or 2,520 days.

But are "seven times" 2,520 twenty-four- days? No. With God each day counts for a year. At Numbers 14:34 God's rule is "a day for a year, a day for a year". And at Ezekiel 4:6 (A.S.) God appointed "each day for a year". So the 2,520 days become 2,520 years. This makes the 
"seven times" of the "appointed times of the nations" 2,520 years long.

Now since the "appointed times of the nations" began in 607 B.C., we must count forward 2,520 years. Where does that bring us? To the year 1914 (A.D.) This is the year marked in the Bible for the ,appointed times of the nations" to end. It is the year for Christ, the one "whose right it is", to be given the heavenly kingdom. ").

Dat bogenoemde redenasie suiwer spekulasie is en dat die Bybel op dié wyse skandelik misbruik word, is vir elkeen baie duidelik. Hierdie feit is onbetwisbaar, indien daar net op die volgende inkonsekwensies gelet word: Die Jehova Getuies stel in hulle redenasie een dag gelyk aan een jaar met 'n beroep op Esegiël 4:6. Maar wanneer hulle handel oor die skepping van alle dinge deur Jehova God, dan stel hulle in dieselifde boek een dag gelyk aan 7,000 jaar:-

The time had now come to start getting the earth ready for the animals and humans that would later live on it. So a period began that the Bible calls the "first day." This was not a day of twenty four hours, but was instead 7,000 years long. ${ }^{2}$ ).

Op grond waarvan hulle dit beweer is nie duidelik nie. Maar daar eindig dit nie! Een dag word ook gelykgestel aan 1,000 jaar - weereens in dieselfde boek:-

When God warned Adam against eating from the forbidden tree, he said : "In the day you eat from it you will positively die". (Gen. 2:17). This did not mean Adam would die within twenty four hours after eating the fruit. It is written at 2 Peter 3:8, that "one day is with Jehova as a thousand years". So instead of living for ever Adam would now die within a period of one thousand years, which is spoken of as a day. And this he did, for he died at the age of 930 years.)

1) From Paradise Lost to Paradise Regained, p. $170-173 \mathrm{Vgl}$. ook: Die Waarheid sal Julle Vrymaak, Hoofstuk 18 en : Laat God Waaragtig wees, bls. $243-246$.

2) From Paradise Lost to Paradise Regained, p. 34. Uit bogenoemde aanhaling spreek dit ook baie duidelik hoe die Jehova Getuies die Bybel misbruik. want daar word slegs 'n gedeelte van die teks aangehaal. 2 Petrus 3:8 lui nl. asvolg: ..Maar laat hierdie een ding julle nie ontgaan nie. geliefdes. dat een dag by die Here soos duisend jaar is en duisend jaar soos een dag". Die laaste gedeelte van die teks word eenvoudig verswyg! 
Verder is dit merkwaardig dat die Adventis William Miller ook met 'n beroep op Esegiël 4:6, maar met 'n ander uitgangspunt nl. Daniël 8:14, ook sulke berekeninge gemaak het ten opsigte van die wederkoms van Christus. Sy berekeninge het egter op die jaar 1843 uitgekom. ${ }^{4}$ ).

As ons nou die glasheldere woord van Jesus in gedagte hou: „Maar van dié dag en dié uur weet niemand nie, ook nie die engele van die hemele nie, maar net my Vader alleen". (Matt. 24:36 en Mark. 13:32), dan mag ons met reg beweer dat hierdie mense die Bybel nie laat spreek nie, maar dit laat buikspreek -dus uit die Bybel laat kom wat hulle daaruit wil hoor.

Tenslotte kan miskien nog net daarop gewys word dat die mees aanvaarde datum van die finale vernietiging van Jerusalem deur Nebukadnesar en die wegvoering van koning Zsdekia, nie 607 v.C. was nie, maar wel 587 of 586 v.C.

t) Vgl. F. Boerwinkel, a.w., blz. 250. Ook: H. C. J. Flemming, a.s., bls. 72; ens. 


\section{DIE CHRISTOLOGIE VAN DIE JEHOVA}

\section{SE GETUIES}

\section{(A) PREEKSISTENSIE}

Jesus Christus as die Seun van Jehova God het 'n voormenslike bestaan gehad. Maar Hy was nie van ewigheid af nie, want Hy het ook 'n begin gehad.

At the time of his beginning of life he was created by the everlasting God, Jehova, without the aid or instrumentality of any mother. In other words, he was the first and direct creation of Jehova God. As such he was Jehovah's only begotten Son. ${ }^{1}$.

Hy word die „eniggebore Seun” (vgl. Joh. 1:14), omdat Jehova God geen deelgenoot gehad het in die voortbring van sy eersgebore Seun nie. Jehova het sy Seun geskape as 'n geestelike skepsel en as die eerste in sy hele skepping.

Hy praat so van homself in Openbaring (of Apokalips) 3:14: „Hierdie dinge sê die Amen, die getrous en waaragtige getuie, die begin van die skepping van God". Ook word van hom in Kolossense 1:15 gespreek as die Een wat die „Beeld van die onsienlike God, die Eersgeborene van die hele skepping" is. In daardie orde word hy dus gestel met Gods skepsele, die eerste onder hulle en ook die mees geliefde en mees begunstigde onder hulle. ")

Omdat Jehova hom geskape het, was hy wel ,in die gestalte van God", maar was nie Jehova God Self nie. Hy was 'n magtige geestelike persoon, maar was nie álmagtig soos Jehova nie. Hy was wel 'n god, maar nie Gód self nie. Dit is duidelik wanneer Johannes hom as die Logos van God beskrywe in Joh. 1:1: ,In 'n begin was die Woord, en die Woord was met die God en 'n god was die Woord. Dit was in 'n begin met die God. ${ }^{3}$ )

Dat die Seun van God dus 'n voormenslike bestaan gehad het, is baie duidelik, want Hy het ook self daarvan getuig. (Vgl. bv. Joh. 6:62; Joh. 8:23 en 58; Joh. 17:5). Hy kan dan in sy preëksistente bestaan geīdentifiseer word met die aartsengel Migael wat in die Ou Testament by name genoem word. (Vgl. Dan. 10:21 en 12:1).

1) „The Kingdom is at Hand", p. 46 and 47.

2) Laat God Waaragtig Wees, bls. 34 .

3) Laat God Waaragtig Wees, bls. 35. 
Maar die Seun was nie net Jehova God se eerste skepsel nie, Hy was ook die skeppingsmiddelaar.

When God said „Let us make man" he was speaking to someone in heaven. To whom? To a mighty spirit creaturc he had made long before he began creating the earth. Through this spirit creature God had created all things. ${ }^{*}$ ).

As skeppingsmiddelaar was Hy egter nie die outeur van die skepping nie, want Jehova het hom net as instrument gebruik. Die Seun het nie as Gód die skeppingswerk verrig nie, want Hy was maar ' $n$ god, goddelik. Tog het hierdie goddelikheid beteken dat Hy so 'n magtige wese was dat Jehova deur Hom alles in hemel en op aarde kon skep.

Jehovah could use this only begotten Son to create such other things, because this Son was the direct offspring of the Almighty One and hence was a mighty one or a god. ${ }^{5}$ ).

Jehova God het Hom dus as sy eersgebore Seun geskape en hom daarna as Sy werkende vennoot gebruik in die skep van die hele res van die skepping. (Vgl. Kol. 1:5-18 en Joh. $1: 1-3)$.

(B) MENSWORDING EN AARDSE BESTAAN.

\section{(1) Geboorte}

Op Jehova se bestemde tyd is die Paradysbelofte van die Saad van die ,vrou" vervul in Bethlehem. Die Seun van God het na die aarde gekom en is gebore in die lyn van Dawid, omdat Sy maagdelike moeder Maria van Dawid afgestam het. Maar die Seun van God het geen aardse vader gehad nie, omdat Jehova God Self sy Vader was. Deur Jehova se gees of wonderwerkende $\mathrm{krag}$ is die lewe van die Seun uit sy heerlike posisie in die hemel verplaas na die embrio van 'n mens.

Months preceding this miraculous event the beloved and only begotten Son of God, "The Word", disappeared from among the holy angels of heaven. He was divested or emptied himself of all his celestial glory and power and had submitted to his heavenly Father's purpose to transfer his

1) From Paradise Lost to Paradise Regained, p. 19.

") „The Kingdom is at Hand”, p. 47. 
life from the heavenly organism to the womb of a faithful Jewish virgin. ${ }^{6}$ ).

Die Seun is uit die maagd Maria gebore as die mens Jesus. Hy was 'n volmaakte mens en sonder sonde, nie omdat hy uit 'n maagd gebore is, of omdat hy géén aardse vader gehad het nie, maar omdat Jehova God Self sy Vader was en Hy Sy Seun deur Sy werkende krag as mens verwek het in die maagd Maria. Hy het dus net 'n menslike liggaam uit Maria ontvang, terwyl sy lewe uit Jehova God Self was.

Met die geboorte van Jesus het die belofte van die Saad van die "vrou" wat die slang se kop sou verbrysel en die belofte aan Abraham dat al die nasies van die aarde in sy saad of nageslag geseën sou word, in vervulling gegaan. Die Seun moes as mens gebore word, sodat hy as volmaakte mens absolute gehoorsaamheid aan die wil van sy Vader kon bewys en daardeur die Koningskap in Jehova se universele organisasie kon verwerf, om as die Koning die Satan se kop te verbrysel en Jehova se Naam te regverdig.

\section{(2) Doop.}

Jesus het groot geword en gegroei in die kennis en wysheid van sy Vader. Op twaalfjarige ouderdom het hy reeds bewus geword dat hy 'n sending het in ooreenstemming met die wil van sy hemelse Vader. Op dertigjarige leeftyd het hy dan na Johannes die Doper gekom om gedoop te word. Tenspyte van Johannes se teenstribbeling het Jesus hom oortuig dat hy wel gedoop moet word, al het hy self nie sonde gehad nie, omdat sy doop ' $n$ ander betekenis gehad het.

Wat was dan die betekenis van Jesus se doop? Deur sy waterdoop het Jesus getoon dat hy homself onderwerp om God se wil te doen. Hy het homself aan Jehova God gekonsekreer of toegewy om Hom alleen te gehoorsaam. Om Sy instemming daarmee te betoon, het Jehova God hom met Sy heilige gees gesalf en toegewy.

In Jesus' case, the spirit's descent upon him was evidence that his consecration to God was accepted, that he was taken into a covenant of sacrifice as the ransom for sinful humankind, and that he was appointed or commissioned to the service of the "kingdom of heaven". ").

\footnotetext{
") ,The Kingdom is at Hand". p. 207 and $208 \mathrm{Cf}$. also From Paradise Lost to Paradise Regained, p. 127.

¡), The Kingdom is at Hand", p. 264.
} 
Deur Jesus as Sy geliefde Seun te erken, het Jehova hom verwek om weer 'n keer Sy geestelike Seun te wees in plaas van 'n blote menslike seun.

Daardie verklaring het getoon dat Christus daar deur Gods heilige gees gesalf is om 'n geestelike seun te wees; 'n blote mens kon nie die Koning van die hemelse regering wees nie. - Hand. 13:30; I Kor. 15:50. ").

Jesus was bestem om die lang beloofde Messias of Christus te wees. Deur Sy heilige gees op die gedoopte Jesus uit te stort, het Jehova God hom met die gees gesalf tot die beloofde Koning in God se Koninkryk. Die hoofdoel waarvoor hy na die aarde toe gekom het, was naamlik om te getuig vir Jehova se Koninkryk waardeur Sy Naam en soewereiniteit geregverdig sou word, en om deur sy absolute gehoorsaamheid te bewys dat hy werd is om die Koning te wees in Jehova se hemelse Koninkryk. Maar hy kon dit nie wees as gewone mens nie. Daarom is hy deur die gees tot 'n geestelike Seun, 'n nuwe skepsel verwek.

A mere man, such as Jesus had been born to be from Mary's womb, could not be King in the "Kingdom of heaven". The Scripture rule forbids it, saying „Flesh and blood cannot inherit the kingdom of God". (I Corinthians 15:50). It was not as a human creature that Jesus was appointed to the Kingdom. Though he was yet in the flesh, it was as a "new creature' 'that Jesus was appointed.

En verder :-

At that event God's "woman", or heavenly universal organization, brought forth the Seed whom Satan hates. ').

Jesus se toewyding aan Jehova by sy doop en sy daaropvolgende salwing tot geestelike Seun, het beteken dat hy sy menslike vlees sou moes aflê en opoffer. Dit sou geld as 'n offerande vir die sondes van die mensdom, waarna hy die Koningskap as geestelike Seun in Jehova se Koninkryk en op Sy bestemde tyd sou ontvang.

Omdat Jesus daardeur gebind was om sy menslikheid vir ewig as 'n offer op sy te lê, het God hom deur sy gaes verwek om weer 'n geestelike Seun van God te word. Daarom het Jesus gesê: „Die Seun van die mens het nie gekom om gedien te word nie, maar om te dien en sy siel

s) Lant God Waaragtig IVees, bls. 119 .

9) "The Kingdom is at Hand" o. 214 and 215. 
(lewe) te gee as 'n losprys vir baie". (Mattheüs 20:28). Hy het dus sy menslike lewe vir ewig afgelê. ${ }^{10}$ ).

\section{(3) Versoeking in die Woestyn.}

Direk na sy doop in die Jordaan is Jesus deur die gees van God weggelei in die wildernis in. Hier in die woestyn het hy vir veertig dae lank gevas, waartydens hy sy hart, gedagtes en bepeinsinge gerig het op sy Vader en op die taak wat hy moes verrig. Deur die salwing van die heilige gees met sy doop, het Jehova Sy Seun op 'n besondere wyse verlig, sodat hy die hemelse dinge kon waarneem en verstaan. Onder hierdie geestelike verligting van die heilige gees, het Jesus sy Vader se wil bestudeer soos dit profeties voorsê is in die Skrifte en soos hy dit van sy Vader geleer het voordat hy mens geword het. Die gees van sy Vader het hom nou sodanig verlig dat hy daardie ooreenkoms met sy Vader baie duidelik kon onthou.

Aan die einde van die veertig dae het Satan, die ou slang, bedrieër en teenstander skielik sy verskyning gemaak. Met alle lis tot sy beskikking en met woorde uit die Skrifte, het die Satan probeer om Jesus te laat afsien van die weg van absolute gehoorsaamheid aan die wil van sy Vader. Drie keer het hy ' $n$ poging aangewend en daarvan was die laaste poging die hewigste.

Jesus se koms na die aarde was om as Koning gesalf te word en om te bewys dat hy die Koningskap in Jehova se Koninkryk werd is. Daarvoor moes hy absoluut gehoorsaam wéés én bly aan die wil van sy Vader en dit weer het veel smarte, beproewings en lyding ingehou. Maar nou skilder die Satan vir Jesus 'n panorama van al die wêreldlike koninkryke wat hy sonder enige lyding kon verkry, alleen deur die Satan te aanbid. Dit alles kon sy deel word as hy net sou ontken dat sy eie Vader Gód is, en die Satan as sodanig sou aanroep. Maar Jesus het baie duidelik gesien dat dit eintlik gaan om die vraag: wie is God, Satan of Jehova? Die Satan was nie werklik van plan om al die aardse koninkryke aan Jesus oor te gee nie. Hy wou alleen dat Jesus hóm sou gehoorsaam in plaas van sy eie Vader. Sy eintlike bedoeling was dus om Jesus tot ongehoorsaamheid te bring en om sodoende die Naam van Jehova God finaal oneer aan te doen.

Rather, it must enhance the Devil in the eyes of all living creation and must enable him to liurl further defiance

1ii) Laat God Waaragtig Wees, bls. 41 
and reproach into the face of Jehovah. A contest for domination was now on. Satan's world domination was fitted against Jehovah's domination over all the universe. ${ }^{11}$ )

Maar die Satan kon nie daarin slaag om hóm wat tot Koning gesalf was, enige skade aan te doen of te vernietig nie. Want Jesus het homself doelbewus en gewilliglik toegewy aan die universele regering van Jehova God en hy sou nooit in ongehoorsaamheid teen hierdie konsekrasie aan sy Vader handel nie. Daarom het Jesus die Satan ondubbelsinnig geantwoord: "Gaan weg agter my Satan; want daar is geskrywe: Jy moet die Here Jou God aanbid en Hom alleen dien". (Matt. 4:10). Hierdie beslissing van Jesus was van die allergrootste belang vir die ganse mensdom. Die gevolge daarvan is ook en veral vir die twintigste eeu van betekenis, omdat die gebeure in die woestyn die begin was van die oorwinnings oor Satan wat in die nabye toekoms sy finale fase sal ingaan.

The outcome of the tests causes our every confidence to be fixed in the Son of God respecting all our good hopes for the future. Only one such as he is worthy to be Ruler in the "kingdom of heaven". His kingship alone is of divine right. His rule is sure to be for the vindication of the name of the Universal Sovereign, Jehovah God and for the everlasting unity and peace of all the universe. ${ }^{12}$ ).

\section{(4) Lyding en Sterwe.}

Die hoofdoel waarvoor Jesus na die aarde gekom het, was om te getuig vir die Koninkryk van Jehova God en om te bewys dat hy werd is om Koning te wees in daardie Koninkryk, deur in alle lyding en versoeking absoluut getrou te bly aan die wil van sy Vader. Gedurende die drie en 'n half jaar na sy doop het Jesus dan ook getuienis afgelê vir die Koninkryk van sy Vader en aan die einde van sy lewe het sy getuienis die klimaks bereik voor die Joodse Raad en Pontius Pilatus. En gedurende hierdie tyd was die Satan met al sy listigheid gedurig gereed om die gesalfde Koning tot ongehoorsaamheid te bring en hom tot niet te maak.

Die nag in Getsemane het die uur van die vyand aangebreek. Satan, die ou slang het gereed gelê om die Koning die Saad van die „vrou" in die haksteen te byt.

11) ,.The Kingdom is at Hand", p. 27.

12) „The Kingdom is at Hand". p. 29. 
Satan the Serpent and his chief earthly seed, the religionists, were engineering a speedy violent death to the Seed of God's woman. That becomes manifest from the first court before which Jesus was brought and tried, a religious court, the Jewish Sanhedrin. ${ }^{13}$ ).

Voor die Joodse Raad het Jesus baie duidelik op die vraag van die Hoëpriester Kajafas, geantwoord dat hy die Christus, die Seun van God, is. Op sy getuienis het die Joodse Raad hom ter dood veroordeel. Daarna is hy verhoor deur Pontius Pilatus voor wie Jesus se laaste toets van getrouheid gekom het en waar hy die klimaks van sy getuienis vir die universele soewereiniteit van Jehova God bereik het. Op 'n vraag van Pilatus of Jesus die Koning van die Jode is, het hy getuig dat sy Koninkryk nie van hierdie wêreld is nie, maar dat dit in die hemele is. Op 'n verdere vraag van Pilatus het Jesus gewys op die hoofdoel van sy sending :-

Pilate asked: „Art thou a king then ?" Jesus now pointing to his chief and primary mission in coming from heaven to earth, said : „Thou sayest that I am a king. To this end was I born, and for this cause came I into the world, that I should bear witness unto the truth . . ." ${ }^{14}$ ).

Maar die ondergeskikte taak wat Jesus ook moes volbring was :.... om as 'n heilige offer aan Jehova God te sterf om die sondes van gelowige mense te kanseleer en om hulle van die oordeel van die dood te bevry, .... . Jesus was bevoeg om so 'n losprys of afkopende offer te wees .... . Toe hy hom dus in volle toewyding aan Gods wil aangebied het, het Jehova hom as 'n offer, as die mens se Vrykoper aangeneem. ${ }^{15}$ ).

Die verbond wat Jesus met Jehova God aangegaan het in sy doop, naamlik om sy mensheid as offer af te lê, sou Jesus ten volle uitvoer, - hy sou sy integriteit teenoor Jehova God bewys. Daarom het hy geen teenstand gebied nie, maar het homself gewilliglik tot die dood laat veroordeel, bespot, pynig en aan 'n hout laat nael, - hy is nie gekruisig nie, maar is aan 'n paal gespyker. (Vgl. Deut. 21:23; Gal. 3:13; en Hand. 5.30).

Jesus se offer het beteken dat hy sy lewe moes aflê. So het $\mathrm{h}$ yself getuig en Mattheüs 20:28 waar "sy siel” beteken sy

1:) „The Kingdom is at Hand", p. 245.

11) "The Kingdom is at Hand", p. 248.

ii) "Laat God Waaragtig Wees, bls. 40 en 41. 
aardse lewe, sy liggaam, sy mensheid, sy menslike natuur. Hy moes dit aflê, om dit nie weer op te neem nie.

He had not taken human nature to stay a man for ever, but in order to make proof of his integrity towards God down here and then to sacrifice that humanity for ever for a man's benefit .... He came offering himself as a sacrifice, to lay aside his perfect human nature and its life-rights. ${ }^{16}$ ).

Nadat Jesus die asem uitgeblaas het, was hy volkome dood. Omdat hy 'n méns was, was hy sterflik, en het hy ook gesterf, soos alle ander mense. Dit beteken (volgens die Jehova Getuies): „Dood na siel én liggaam”. Só was Jesus vir drie dae lank in die hel $(=$ hades $=$ graf $)$.

Dus sien ons dat hades die Griekse gelyke van sheol is. Die oorspronklike woord in albei tale beteken graf, ' $n$ toestand waar niks gesien kan word nie; en daarheen is dit waar die Seun van God vir drie dae gegaan het. ${ }^{1 i}$ ).

Op dié wyse het die Satan daarin geslaag om die Saad van die "vrou" in die haksteen te byt. Maar hy sou niks meer as dit regkry nie; hy sou die Saad nie vernietig nie, omdat Jesus die belofte van sy Vader gehad het dat Hy hom nie in die dood sou laat nie, maar hom sou opwek as beloning vir sy absolute gehoorsaamheid aan die wil van sy Vader en sy getrouheid aan die Koninkryk van Jehova God, selfs tot in die dood.

\section{(C) POSTEKSISTENSIE.}

\section{(1) Opstanding}

Op die derde dag na sy dood het Jehova Sy belofte gestand gedoen en Jesus uit die dode opgewek. Hy is egter nie opgewek as die mens Jesus, as 'n menslike seun nie, maar as 'n magtige geestelike Seun, met alle mag in hemel en op aarde, net onder die Almagtige God, Jehova. Sy volmaakte menslike lewe, met al sy regte en vooruitsigte, het Jesus nie by sy opstanding teruggeneem nie, maar hy het dit in die dood afgelê. Dit was sy offer vir die sonde van die mensdom. Hy is dus nie liggaamlik opgewek nie, maar as 'n onsterflike, goddelike geestesskepsel. Daarvan het die apostel Petrus getuig toe hy van Jesus gesê het: „Doodgemaak in die vlees, maar lewen-

1i) "The Kingdo mis at Hand", p. 214 Cf. also p. 254.

ii) Laat God Waaragtig wees, bls. 73 . 
dig gemaak in die gees". (I Petrus 3:18; A.S.V. en Douay vertaling.) Jesus is dus in die vlees gedood, - die mens Jesus het gesterf, dit wil sê, het totaal tot niet gegaan; maar hy is in die gees opgewek, - die geestelike skepsel wat deur Jehova se gees verwek is, het opgestaan.

Vir veertig dae lank na sy opstanding het Jesus aan sy dissipels verskyn in gematerialiseerde vorm, netsoos die seuns van God in die begin van die mensdom se geskiedenis gedoen het, toe hulle omgang met die dogters van die mense gehad het en soos die engele telkens gematerialiseer het in hulle verskynings aan die mense.

Therefore the bodies in which Jesus manifested himself to his disciples after his return to life were not the body in which he was nailed to the tree. They were merely materialized for the occasion, resembling on one or two occasions the body in which he died, but on the majority of occasions being unrecognizable by his most intimate disciples. The body which was put in the sepulchre was disposed of without corruption according to God's prophecy and by his almighty power. ${ }^{\text {") }}$.

Jesus was die eerste een wat uit die dode opgewek is; maar hy sou nie die enigste wees nie. Sy opwekking was 'n bewys of versekering vir die getroue gelowiges sodat hulle in volle vertroue kon steun op hulle eie hemelse opstanding wat deur Jehova God beloof is. Dit is ook die belofte vir hulle wat die aardse opstanding sal ontvang. ${ }^{19}$ ). Jesus was dus nie die enigste nie, maar was net die eerste. Daarom word van hom gepraat as „die Eersgeborene uit die dode", „die eersteling . . . van die wat ontslaap het". (Kol. 1:18; I Kor. 1-5:20).

\section{(2 Hemelvaart en Verhoging.}

$\mathrm{Na}$ die veertig dae van omgang van Jesus met sy dissipels, het Jesus vir die laaste keer gematerialiseer en aan sy dissipels verskyn om van hulle afskeid te neem. Daarna het Jesus voor die oë van sy paar vertrouelinge, opgevaar na die hemel, terwyl hulle dit aanskou. Maar Jesus het nie liggaamlik opgevaar nie, want hy is as magtige geestesskepsel opgewek en as sodanig het hy opgevaar na die hemel. Die liggaam waarin sy

18), The Kingdom is at Hand", p. 259.

$\left.{ }^{9}\right)$ Vgl. vir onderskeid tussen hemelse en aardse opstanding: Laat God Waaragtig Wees, Hoofstuk 21, bls. 268 en 27. 
dissipels hom sien opvaar het, was net 'n gematerialiseerde liggaam, sodat hy sigbaar kon wees vir sy dissipels.

In die hemel het Jesus voor Jehova God verskyn met die waarde van sy menslike offerande as Jehova se Hoëpriester. (Vgl. Hebr. 9:11, 23 en 24; 10:12 en 13).

Nadat die hemelse Vader aan sy getroue Seun die loon van onsterflike geestelike lewe gegee het, het die geofferde menslike lewe van krag gebly, 'n ding van waarde met koopkrag, en dus met vrykoop - of loskoopkrag. Die waarde van die volmaakte menslike lewe was nou beskikbaar om in belang van getroue mense wat behoefte gehad het om daardeur vrygekoop te word, te gebruik. ${ }^{21}$ ).

Vir sy nederige lewenswandel en sy absolute gehoorsaamheid aan sy Vader se wil, het Jehova God vir Jesus as beloning nog hoër verhoog as wat hy was in sy voormenslike bestaan. Die apostel Petrus sê :,.... deur die opstanding van Jesus Christus wat heengegaan het na die hemel en aan die regterhand van God is, nadat engele en magte en kragte aan hom onderwerp is". (I Petrus 3:21 en 22. - vgl. ook Fil. 2:9). Hierdie is dan ook 'n duidelike bewys dat Jesus nie sy menslike liggaam na die hemel geneem het om vir ewig 'n mens in die hemel te wees nie, want dan sou hy vir ewig minder as die engele gewees het. Maar nou het Jehova hom as magtige, geestelike Seun sodanig verhoog dat hy die Hoof kan wees van Jehova se hemelse organisasie, aan niks of niemand ondergeskik, behalwe aan Jehova alleen nie.

If Jesus had been equal with God before being ,made flesh", the Almighty God could not have further exalted Jesus, because that would have required that Jehovah exalt Jesus higher than himself, an impossibility and most unreasonable ! ${ }^{21}$ ).

\section{(3) Wederkoms}

Terwyl Jesus op die aarde was, was dit nog nie sy Vader se bestemde tyd om die Koninkryk op te rig nie, Hy het wel gedurende hierdie tyd bewys gelewer dat hy werd is om Koning te wees in Jehova se teokratiese Koninkryk. Ook na sy hemelvaart en verhoging is die Koninkryk nog nie opgerig nie. Want Jehova God het deur Dawid gesê : „Sit aan my regterhand totdat Ek u vyande gemaak het 'n voetbak van u voete" (Vgl. Ps.

2") Laat God Waaragtig Wees, bls. 98 .

21) "The Kingdom is at Hand", p. 50 
$110: 1-3)$. Jesus moes dus in die hemel wag tot op Jehova se bestemde tyd vir die oprigting van die Koninkryk. En hierdie bestemde tyd is dié tyd wanneer die einde van die „tye van die nasies" sou aanbreek, naamlik in 1914. (Vgl. Luk. 21:24).

In die jaar 1914 het die onuitwisbare voorneme van Jehova God om Sy regverdige Koninkryk op te rig in vervulling gegaan. In daardie jaar is Jehova se Koninkryk gebore, toe Sy universele organisasie, Sy „vrou”, die Koning Jesus Christus voortgebring het. Die hemelse organisasie van die Satan het onmiddellik probeer om die pasgebore Koninkryk te verslind. Dit het gelei tot 'n hewige oorlog in die hemele. Die oorwinning is behaal deur die Koning van die pasgestigte Koninkryk en die Satan is met sy hele organisasie uit die hemel neergewerp op die aarde. Die hemel is so gesuiwer van alle teenstand met die gevolg dat dáár nou alleen God se wil gedoen word. Uit boosheid oor sy verpletterende neerlaag het die Satan die een nasie in woede teen die ander nasie laat ontvlam en het dit gelei tot die Eerste Wêreldoorlog in 1914.

Juis hierdie verpletterende oorlogsgebeure was een van die sigbare tekens wat deur Jesus voorspel is en wat die bewys sou wees van die onsigbare gebeure in die hemel en die aankondiging dat die wederkoms van Christus voor die deur is. (Vgl. Matt. 24:6 en 7 en Openb. 11:18). 'n Verdere sigbare teken van die onsigbare oprigting van die Koninkryk in die hemele was : „Hierdie Evangelie van die Koninkryk sal verkondig word in die hele wêreld tot 'n getuienis vir al die nasies". (Matt 24:14).

Presies dieselfde aankondiging wat in 1900 jaar gelede gemaak is, is weer van 1914 af laat herleef en met selfs groter omvang as in die begin aangekondig. Van en na die jaar 1919 was die aanhoudendste publisiteitskampanje wat nog ooit op die aarde gegee is tot die affek (= effek J.H.B.) dat ,die koninkryk van die hemele naby gekom het”! „Hierdie evangelie" is dat die Koninkryk in 1914 n.C. opgerig is. ${ }^{22}$ ).

Bogenoemde was slegs twee van die sigbare tekens wat nodig was, sodat die mense kon weet dat die Koninkryk opgerig is en dat Christus gou kom om te oordeel. Dit alles, ook die wederkoms, sou vir die gewone alledaagse mense onsigbaar wees, en sou alleen deur Jehova se getroue getuies gesien word. Daar het $\mathrm{nl}$. lank 'n verkeerde verwagting bestaan oor die we-

22) Laat God Waaragtig Wees, bls. 125. 
derkoms van die Here. Die sinnebeeldige verklarings van die Bybel oor die wederkoms, is verkeerdelik letterlik verklaar sodat daar verwag is dat die verheerlikte Jesus op 'n wolk sou kom waar elke oog hom sou sien. Daar word dan 'n beroep gedoen op die woorde van die engele by die hemelvaart: „Hierdie Jesus wat van julle opgeneem is in die hemel, sal net so kom soos julle Hom na die Hemel sien wegvaar het". (Hand. 1:11). Maar hierdie teks praat net van die wyse of maniere waarop hy weggegaan het, en dit was stil, soos 'n dief, sonder trompet geklank en openbare vertoon. Alleen sy dissipels, sy getuies het hom sien gaan en daarom is dit logies dat alleen sy getroue getuies hom weer sou sien kom - want die belofte is net aan hulle gegee.

Maar sy wederkoms is nie met die vleeslike oë gesien nie, maar met die oë van die verstand, wat deur God se Woord verlig is. Christus se nabyheid en teenwoordigheid word nie onderskei deur sy liggaamlike aanwesigheid nie, maar deur sy oordeelsdade wat duidelik waargeneem kan word en tesame daarmee deur die vervulling van Bybelprofesieë.

So beteken ook die Griekse woord vir wederkoms nl. parousia nie in die eerste plek "koms" nie, maar "teenwoordigheid".

Dit dui daarop dat Christus reeds gekom het en dat hy teenwoordig is. Dit was nie vir hom nodig om sigbaar te kom nie, netsoos ook Jehova God vir die menslike oë onsigbaar is. In werklikheid kán hy ook nie sigbaar wees nie, omdat hy as 'n heerlike, geestelike skepsel gekom het.

Jehova God het deur Sy profeet Maleagi Sy skielike verskyning by Sy tempel voorsê en die voorafgaande kom van Sy Boodskapper na die tempel (Mal. 3:1 en 2). Soos Jesus drie en 'n halwe jaar nadat hy in sy doop gesalf is tot Koning deur God se gees, na die tempel gegaan en dit gereinig en gesuiwer het (Matt. 21:12-17), netso het hy drie en 'n halwe jaar nadat hy in die najaar van 1914 die Koninklike beheer oorgeneem het, as Jehova se Boodskapper na Sy geestelike tempel gekom in die jaar 1918 - die suiwering van die tempel van Jerusalem was 'n miniatuur vervulling van die profesie van Maleagi wat eers in 1918 volkome vervul is. Dit is dan die datum van Christus se wederkoms, want 1918 het die tyd van oordeel, inspeksie en skeiding van die nasies begin. (Vgl. 2 Tim. $4: 1)$.

Terwyl Christus as Jehova se verteenwoordiger by die 
tempel op die troon van sy heerlikheid aanwesig is, skei hy die mense in twee klasse naamlik die skape en die bokke. Hoewel die meeste mense nie daarvan bewus is nie, is daardie skeiding sedert 1918 aan die gang. Die houding teenoor Jehova se getuies en teenoor die boodskap van Sy teokratiese regering, openbaar die mense se houding teenoor die Koning en daarvolgens vind die skeiding plaas. Die vervolgers, teenstanders en onverskilliges is die bokke wat 'n ewige vernietiging tegemoet gaan, terwyl die sagmoediges en die mense van welwillendheid die ewige lewe kan verwag.

In die jaar 1918 het ook die eerste opstanding plaasgevind. Die getroues wat in hulle grafte geslaap het, is met geestelike liggame opgewek en versamel om by Christus te wees in die geestelike tempel. Die Christene wat vanaf 1918 nog op die aarde was, moes tot hulle dood hulle onkreukbaarheid teenoor Jehova God handhaaf, waarna hulle 'n onmiddellike verandering ondergaan en geestelike liggame ontvang het, sonder om eers in die dood te slaap. So sal dit ook wees met die klein oorblyfsel van getroues wat nog op die aarde is tot met die finale openbaring van Christus in die slag van Armageddon wat in die nabye toekoms lê. Die bestemming van alle mense wat lewe, sal binnekort beslis word. „Want die Seun van die mens staan gereed om met sy engele in die heerlikheid van sy Vader te kom, en dan sal Hy elkeen vergeld volgens sy dade". (Matt. 16:27). Die finale openbaring van die Koning, wat reeds onsigbaar aanwesig is, nader baie vinnig. Die ramp van Armageddon wat groter sal wees as dié wat deur Sodom en Gomorra ondervind is, is voor die deur. In daardie slag sal Jesus Christus as Jehova se Koning op 'n wit perd kom en al die dele van die Satan se organisasie totaal vernictig.

Hy gryp die ou slang, die Duiwel, en bind hom 'n duisend jaar. Deur religie uit die weg te ruim, deur ware aanbidding te herstel, en deur die Goddelike regering weer ten opsigte van die aarde op te rig, openbaar hy sy koninklike mag waarvan hy hom by sy eerste koms waardig bewys het. ${ }^{23}$ ).

Gedurende hierdie tyd sal die Satan geen invloed hê nie. Dit sal die duisendjarige vrederyk wees wanneer Christus as Koning sal regeer en die getroue Armageddon - oorlewendes en miljoene ander mense op die nuwe aarde in vrede sal woon.

23) Laat God Waaragtig Wees, bls. 195. 
Op die gesuiwerde aarde, vry van bose Sataniese invloed, en met die verdienste van Christus se sonde-kansellerende offerande in werking met betrekking tot hulle, sal die oorlewendes van Armageddon, onder die leiding van die Koning en sy vorste, trou en kinders in geregtigheid voortbring, tot eer van God (Spreuke 28:28). ${ }^{24}$ ).

Gedurende hierdie duisendjarige regering sal daar ook biljoene "onregverdige" dodes wees wat opgestaan het en wat onderrig in God se wet sal ontvang. Aan die einde van hierdie tydperk sal die Satan ontbind word en sal hy vir die laaste keer 'n poging aanwend om Jehova se universele soewereiniteit toe te eien en om die hele mensdom teen God te keer. Sommige sal mislei word en sal dan saam met die Satan vir ewig gegooi word in die ,poel wat brand met vuur en swawel: dit is die tweede dood". (Openb. 21:8; 20:10, 14 en 15). Dié wat in hierdie finale geloofstoets hulle onkreukbaarheid behou, sal deelhê aan die finale regverdiging van Jehova se Naam. Dan sal ook Christus self sy heerskappy aan sy Vader oorgee, homself aan Hom onderwerp en dan sal Jehova God vir ewig in vrede regeer en Sy soewereiniteit uitoefen deur alles in almal te wees.

24) Laat God Waaragtig Wees, bls. 265.

2i) Vir meer volledige besonderhede oor die wederkoms van Christus vgl. Laat God Waaragtig Wees, Hoofstukke 15, 19, 20, 21 en 22 en From Paradise Lost to Paradise Regained, Hoofstuk 25 en 29. 


\section{DIE HERLEWING VAN 'N EEUE-OUE DWALING}

\section{(A) ALGEMENE OPMERKINGS}

(1) Die Antitetiese Houding teenoor dogmatiese terme en die eis om die eenvoudige Bybelse waarheid.

Ons het reeds vroeër in die inleidende hoofstuk gewys op die besondere antitetiese houding van die Jehova Getuies teen oor alle Geloofsbelydenisse en sistematiese geformuleerde dogmata. 1). Dit word afgekeur en verwerp as mensewerk en as strydig met die Bybel beskou. Daar word veral teen die dogmatiese terme van die Christelike leerstelling gepolemiseer, omdat die terme nie letterlik in die Heilige Skrif voorkom nie en omdat dit die eenvoudige, suiwere waarheid van die Skrif,, verduister". Terme soos „Drie-eenheid", „Wese”, „Persone”. "nature", ens. is volgens die Jehova Getuies onder invloed van die Griekse heidense filosofie in die suiwere Christelike leer ingevoer.

Tertullianus, . . . . het ter verdediging van sy godsdiens geskrywe en die woord trinitas, wat "drieëenheid" beteken, in sy geskrifte ingebring. Van daardie tyd af aan het dit gekom dat drieeenheidsleer die geloof van voorgewende Christene al hoe meer besmet het. Daardie leerstelling is geheel en al vreemd aan die ware Christendom. . . . en die woord trinitas word selfs in die Latynse vertaling van die Bybel nie gevind nie. ${ }^{2}$ ).

Hierdie opvatting lei daartoe dat die Bybel dan „opnuut” bestudeer word om sodoende die „eenvoudige Bybelse waarheid" weer aan die lig te bring. Dít wat „verduister" is deur allerlei heidens-filosofiese invloed moet gesuiwer word deur net die suiwerste Bybelse terme te gebruik. Die Bybel moet sonder die „verbinding" en "slawerny" van allerlei dogmatiese leerstellinge - wat die werk van mense is, - bestudeer word.

Om die waarheid te bereik, moet ons religieuse vooroordeel uit hart en hoof sit. Ons moet God vir homself laat praat. Enige ander handelswyse sal net tot verdere verwarring lei. ${ }^{3}$ ).

Dit was ook ,doel” van Russell en andere in 1870, waar-

1) Vgl. daarvoor From Paradise Lost to Paradise Regained p. 164 and 165.

z) Wat het Godsdiens vir die Mensdom gedoen, bls. 242.

3) Laat God Waaragtig Wees, bls. 6 
voor die Jehova Getuies asvolg kommentaar lewer:-

At that time a small group of Christians came together to study the Bible. They wanted to return to the true belief and the true work taught by the Bible. ${ }^{4}$ ).

Maar hierdie standpunt ten opsigte van die dogmatiese terme en tesame daarmee die poging om die ,eenvoudige”, ,suiwere" Bybelse waarheid na vore te bring, is reeds baie eeue oud. Dit het in die eerste eeue van die Christelike Kerk reeds voorgekom en het telkens weer in die loop van die geskiedenis van die Kerk sy verskyning gemaak in die vorm van sektes en ketterye. Dit het telkens die pad van die Kerk gekruis en die Kerk weer opnuut laat besin oor die werklike waarheid van die Heilige Skrif. Hierdie hele saak spreek baie duidelik uit dis volgende :-

Dikwels vind ons dat van die ou Kerkvaders hulle teenoor hulle vriende en gemeentes verontskuldig het dat hulle nie met die sinodale dogmatiese uitsprake kon saamstem nie, (al was die uitsprake ook ortodoks), omdat die terme van die uitsprake nie in die Skrif voorgekom het nie. ${ }^{5}$ ).

Dieselfde gedagte vind ons by Arius en sy volgelinge :-

Arius was leerling by die eksegeteskool van Lucianus wat teenoor die tendens om Skrif, tradisie, wysgerige spekulasie tot dogma saam te weef, die suiwer en vry klank van die Skrif soos deur die suiwer rede geīnterpreteer tot gelding te bring. ${ }^{6}$ ).

Baie eeue later in die tyd van die Kerkhervorming, vind ons ook hierdie gedagtes by Calvyn se teenstanders o.a. by Valentinus Gentilis wie se opvatting as volg deur Professor Engelbrecht gestel word:

Gentilis was nie in die eintlike sin van die woord antitrinitariër en Ariaan nie. Hy het (soos baie mense in die tyd van die Kerkhervorming) beswaar gehad teen die terme Triniteit, Wese, Persoon, Relasie, Eienskap e.s.m., omdat dié terme nie in die Bybel voorkom nie ... Gentilis se bedoeling was om die eenvoudige Bybelse gegewens sonder-

4) From Paradise Lost to Paradise Regained, n. 169.

5) B. J. Engelbrecht. Enkele Dogmaties? Onmerk'nra on- dis Kerklike leer aangaande die Triniteit. met besondere verwysino na die Stotus van die Pre- en die Posteksistente Christus ten opsigte van die Vader, Pretoria 1964. Hervormde Teologiese Studies Jrg. 19. bls. 139.

i) B. J. Engelbrecht, a.w., bls. 156 
papistiese en skolasties-filosofiese onderskeidinge aan die mense deur te gee. ').

Calvyn sê oor hierdie mense se opvatting die volgende :-

Het zou beter zijn, zeggen ze, niet alleen onze gevoelens maar ook onze woorden binnen de grenzen der Schrift te houden dan vreemde woorden uit te strooien, die later kweekplaatsen van onenigheden en twisten kunnen zijn. Want zo tobt men sich af met woordenstrijd; zo verliest men al debatterend de waarheid, ... . ${ }^{*}$ ).

Bogenoemde houding en opvatting is ' $n$ tipiese kenmerk van dié groepe in die Christendom wat deur hulle poging om die „eenvoudige" Bybelse waarheid na vore te bring, spoedig tot loëning van die kernwaarhede van die Skrif gekom het. Dit is telkens weer in die Kerk se geskiedenis onbetwisbaar bewys. Daarom is die opvatting van die Jehova Getuies geen nuwe nie, maar is net die herhaling van 'n opvatting wat reeds baie eeue oud is - ja, wat die Kerk van die begin af voortdurend bedreig het.

\section{(2) Die Noodsaaklikheid van dogmatiese terme.}

Die oeroue en kortste formule vir die Drie-eenheid is in Grieks : mia ousia, treis hupostaseis (Latyn: Una substantia, tres personae) $=$ Een Wese, drie Persone. Nou kom die vraag op: Is hierdie dogmatiese terme en andere (soos bv. Trinitas (Drie-eenheid), propreïtas (eienskap), homo - ousios (Eenswesens,) Status, ens.) werklik só noodsaaklik en essensieël ? Is dit uiteindelik nie maar beter om te bly by die eenvoudige Bybelse waarheid en Bybelse terme nie, sodat ten opsigte van bv. die Triniteit dit genoegsaam is om net die eenvoudige Trinitariese doopbevel te handhaaf: „.... en doop hulle in die Naam van die Vader en die Seun en die Heilige Gees; ... . (Matt. 28:19. Vgl. ook 2 Kor. 13:13)?

Die antwoord op bogenoemde vrae is: As die Kerk gevrywaar was van alle sektariese strominge en ketterye, sou hierdie vrae beslis sonder twyfel bevestigend beantwoord kon word. Dit was ook die opvatting van die Reformatore, soos Luther en Calvyn. Calvyn sê o.a. oor die terme :

Waren ze maar begraven, wanneer slechts dit geloof bij allen vasstand, dat de Vader en de Zoon en de Geest één

7) B. J. Engelbrecht. a.w., bls. 178.

4) A. Sizoo, Johannes Calvyn Institusie, Amsterdam 1956, DI. I. I, blz. 100. 
God zijn, en dat toch niet óf de Zoon de Vader is, óf de Geest de Zoon, maar dat ze door een zekere eigenaardigheid onderscheiden zijn. ").

Dieselfde opvatting is deur Luther, Melanchton en ander teoloë gehuldig. Maar die Reformatore het in hulle stryd teen die dwaalleraars (soos Gentilis, Servet, Sociniane) spoedig uitgevind dat die Kerklik-dogmatiese terme onvervangbaar is.

Die oud Christelike Kerk is deur die Gnostiek van die eerste 4 eeue met sy kompleks van sektariese strominge gedwing om die suiwer Bybelse waarhede duidelik te formuleer en teen alle dwaling af te grens. Omdat die front waarteen die Kerk die Bybelse waarhede moes verdedig, sterk heidens-filosofies beĩnvloed was, was die Kerk genoodsaak om die mees geskikte terme te gebruik wat die suiwere waarheid tot uitdrukking kon bring. Dit is dus nie só (soos deur die Jehova Getuies beweer word) dat bv. die Triniteitsleer onstaan het as gevolg van die heidense filosofie wat in die Kerk self ingedra is nie, maar as gevolg van die heidens-filosofiese front waarteen die Kerk die waarheid moes afgrens. Die dogmatiese terme het dus ontstaan uit die stryd van die Kerk teen die dwaalleer. Calvyn stel dit só :

Zo sijn de ouden, door verschillende strijden tegen valse leerstellingen gedreven, genoopt geweest hun mening met uitgezochte duidelijkheid uiteen te zetten om geen gelegenheid tot slinkse uitvluchten over te laten aan de goddelozen, voor wie de omhulsels van woorden schuilhoeken hunner dwalingen waren. ${ }^{10}$ ).

En G. C. van Niftrik stel :-

Haar geloofsbezit verdedigende tegen velerlei dwaalleer, genoodzaakt sijnde precies te zeggen hoe het naar Gods Woord is, moet de Kerk komen tot het formuleren van geloofsbelijdenis. ${ }^{11}$ ).

Die Kerk is dus genoodsaak om die opvatting van Calvyn, van Niftrik en andere, ten opsigte van hierdie saak te handhaaf, ook en veral teenoor die dwaling van die Jehova Getuies. Hoswel Calvyn dus veel eerder die eenvoudige Bybelse waarhede en terme sou wou gebruik, word hy teenoor die dwaalleer ge-

9) A. Sizoo, a.w., blz. 103.

01) A. Sizoo. a.w., blz. 101.

11) G. C. Van Niftrik, Kleine Dogmatiek, Nijkerk, blz. 26. 
dwing om die oud Kerklike en dogmatiese terme as onvervangbaar te beskou en te handhaaf. Oor hierdie terme se Calvyn dan ten slotte die volgende :-

Maar wat is er tegen om dingen, die in de Schiften voor ons begrip ingewikkeld en moeilijk zijn met duidelijker woorden uit te leggen, maar toch met woorden, die vromelijk en getrouwelijk de waarheid der Schrift zelf dienen, .... ?... E En dergelijke nieuwheid van woorden echter (wanneer ze zo genoemd mag worden) komt dan vooral te pas wanneer de waarheid verdedigd moet worden tegen lasteraars, die door het zoeken van uitvluchten haar ontwijken. ${ }^{12}$ ).

(B) DIE ARIAANSE DWALING IN DIE CHRISTOLOGIE VAN DIE JEHOVA SE GETUIES.

\section{(1) Vooropmerkings.}

Die afwysing van die Ariaanse dwaling in die begin van die vierde eeu n.C., was noodwendig die gevolg van die talle gnostiese strominge wat vanaf die eerste eeu n.C. telekns die Kerk van binne en van buite bedreig het, - van binne, weens die feit dat prominente teoloë die gnostiese dwalinge in die Kerk as die waarheid verkondig het en van buite, weens die populariteit en getalsterkte van die gnostiese strominge. Die Kerk was dus gedwing om die waarheid suiwer te formuleer en duidelik af te grens, soos in die geval van die kettery van Arius.

Die dwaling van Arius $( \pm 300)$ was 'n onderdeel van die stroming van die sg. Monargianisme. Hierdie monargiane het gepoog om die Christelike monotheĩsme, die monarchia (monarchia) van God veilig te stel, deur onder andere 'n adoptiaanse Christologie te leer. Die Adoptianisme leer dat Jesus Christus nie altyd die natuurlike, wesenlike Seun van God was nie, maar dat $\mathrm{Hy}$ na Sy volbragte verlossingswerk as beloning vir Sy getrouheid deur die Vader tot Seun geadopteer (aangeneem) is. So het Hy dan na Sy verhoging die hoogste goddelike rang of status ontvang, gesubordineer aan die Vader alléén. Hierdie adoptiaanse Christologie is dus in wese ook 'n Subordinatianisme.

Hierdie selfde gedagtes het ons ook by Aruis gevind, wat geleer het dat Christus nie waaragtig God was nie maar 'n

12) A. Sizoo, a.w., blz. 101. 
skepsel, 'n mens wat vervul was van die strewe na sedelike volkomendheid. Professor Th. L. Haitjema stel dit onomwonde dat Arius in sy Christologie uitgegaan het van die skepsel-wees en kindskap van God van alle mense :-

Omdat Arius de huiothesia der geloovigen in Paulinischen zin ten eenenmale verwierp, en optimistisch over den mensch oordeelde in zijn ingroeien in het kindschap Gods, daarom was Arius eigenlijk een bestrijder van de leer van de godheid van Christus. Arius ging uit van de leer van het kindschap Gods van alle menschen als schepselen Gods, schepselen van den als scheppingsmiddelaar in zijn hoedanigheid van eerste schepsel; . . . ." ${ }^{1:}$ ).

Hierdie optimistiese beskouing oor die mens lei noodwendig tot die ontkenning van die Godheid van Christus en tot die beskouing dat Hy alleen maar 'n voorbeeld is vir die mens wat in werklikheid self die weg na vergoddeliking kon bewandel in die voetspore van Jesus Christus, die groot Voorbeeld.

Die mens kan hierdie doksa, hierdie heerlike eer, deur deugsame lewe verkry terwyl die mens sy oog hou op die voorbeeld van Jesus Christus wat op hierdie wyse hierdie heerlike eer ontvang het. ${ }^{11}$ ).

Tereg merk Professor B. J. Engelbrecht dan ook nog verder op dat die opvatting van Arius, - nl. dat Jesus nie van ewigheid af God was nie, maar eers na Sy heilswerk vergoddelik is, en dat Hy nie natuurlik die Seun van God was nie, maar op etiese vlak deur wilsgehoorsaamheid die Seun van God geword het in beginsel die weg voorberei het ,tot die latere liberale teologie wat in Jesus Christus bloot 'n menslike voorbeeld sien, ook voorbeeld daarvan dat die mens deur wilsgehoorsaamheid aan die Vader vergoddelik kan word." ${ }^{15}$ ).

Bogenoemde Ariaanse gedagtestruktuur en die gevolge daarvan nl. die beskouing van Christus as blote voorbeeld, het telkens in die verloop van die Dogmengeskiedenis na vore getree.

Tegen deze belijdenis hebben vele ketters en valsche Chritenen alle euwen door tot op heden gestreden. $\mathrm{Zij}$ vallen steeds in twee groepen uiteen ..... De eene groep loochent, dat de Zoon en de Heilige Geeste één van Wezen zijn met den Vader. Zij zien in den Vader alleen God in de

1:) Th. L. Haitiema, Dogmatiek als Apologie, Haarlem 1948, blz. 214.

14) B. J. Engelbrecht, a.w.. bls. 158.

15) B. J. Engelbrecht, a.w., bls. 155 en 156 . 
volle zin ..... Grondleggers van deze dwaalleer zijn de Ebioniete, Arius, Paulus van Samosata, Eunomius e.a. Hun volgelingen worden in alle eeuwen der Kerkhistorie gevonden. Wij noemen als voorbeeld de Sociniane, sommige Remostranten, de Groninger richting, Ritschel en zijn aanhangers en vele hedendaagsche moderne theologen. ${ }^{16}$ ).

Die opvatting van die Sociniane bv. word só uiteengesit deur Prof. Engelbrecht:-

Die Sociniane sê weer dat God eén is in Wese en één in Persoon. Die enige God is alleen die Vader .... Jesus Christus is deur die Heilige Gees verwek, dus deur 'n Goddelike Krag en alleen daarom skryf die Bybel aan Christus Goddelikheid toe - dit wil sê in oneintlike sin. ${ }^{17}$ )

En Dr. G. C. van Niftrik stel verder :-

Socini ... Z Zijn standpunt komt het dichtst bij dat van Arius. In de grond der zaak predikt hij een redelijk-zedelijk christendom met een sterk moralistiche inslag .... . Het komt er voor de mens op aan de geboden Gods, die ons in de Bybel zijn bekendgemaakt, zo goed mogenlijk te houden, en bij sijn terkortkomingen mag de mens vertrouwen op de barmhartigheid van God, die de zondaar, die met ernstig berouw tot Hem komt, vergewing schenkt, om niet. ${ }^{18}$ ).

Dieselfde gedagtestruktuur en gedagteinhoud het ons ook by die teoloë van die sg. „Groninger Godgeleerheid" van die negentiende eeu aangetref. Professor Th. L. Haitjema sit die saak baie duidelik uiteen as hy stel :-

Men behoefte dan ook de Christologie van de Groninger theologen inderdaad niet zoo heel lang te bestudeeren, vóor men het Arianisme en het Origenisme op het spoor zal komen. Jesus is hier niet werkelijk de Theanthrópos, de Godmensch, noch werkelijk éénswezens, homoousios, met den Vader. ${ }^{19}$ ).

En verder :-

Haar trefwoorden waren veel meer: opleiding en vorming tot Godegelijkvormigheid van het mensdom. En

16) A. D. R Polman. Onse Nederlandsche Geloofsbelịdenis, Franeker, DI. I, blz. 315 .

i) B. J. Engelbrecht, a.w., bls. 180.

iv) G. C. van Niftrik, a.w.. blz. 425 en 426

i!) Th. L. Haitjema, a.w. blz. 165. 
de centrale opvoedingsgedagte als het wezen van het christendom deed vanzelf de klassieke kerndogmata van de Kerk van Christus in het duister raken : de Godheid van Christus, de leer der Drieënheid . . . ${ }^{20}$ ).

'n Identiese gedagtestruktuur en opvatting vind ons dan ook terug in die Christologie van die Jehova Getuies. Alvorens ons daartoe oorgaan om dit aan te toon, is dit nodig om eers 'n kort weergawe van die leer van Arius te gee, sodat die wesenlike ooreenkoms van die Christologie van die Jehova Getuies met die leer van Arius duideliker aangetoon sal kan word.

\section{(2) 'n Kort Samevatting van die Leer van Arius}

Die leer van Arius word deur Professor B. J. Engelbrecht as volg kernagtig saamgevat:-

Arius se leer word beheers deur die gedagte dat God een is. Alleen ,die Vader" is die Een, Enige God en alleen Hy is agennétos (vetdruk : J.H.B.) en agenétos (ongebore en ongeword) d.w.s. (vir Arius) geskape en gemaak. As die Skrif dus van die Seun sê dat Hy Monogenés is (Eniggeborene), dan sê die Skrif dat Hy gennétos is, gebore is en dus 'n begin gehad het .... As die Seun 'n begin gehad het, is Hy op een of ander manier gemaak, geskape al is dit eks ouk ontón, uit die nie-synde. Die feit dat die Seun monogenés eniggebore is, gee aan Hom nog nie gelyke ewigheid met God nie, maar wil alleen sê dat Hy nie skepsel is op dieselfde wyse as die ander skepsele dit is nie, maar dat $\mathrm{Hy}$ 'n tussenwese tussen God en die geskapene is. Hy is ktisma teleion (volmaakte skepsel) wat vóór alle andere vóór die tyd (achronós) deur God voortgebring is (gennétos en genétos) uit die nie-synde (eks ouk ontón) en deur wie alle ander skepsele gemaak is. ${ }^{21}$ ).

En Dr. G. C. van Niftrik se slotsom oor die leer van Arius is :-

Voor Arius is Christus dus een halfgod. Hier kunnen wij in Christus nooit God zelf en God helemáál hebben. ${ }^{22}$ ).

Arius het vir bogenoemde opvatting hom veelvuldig op die Heilige Skrif beroep. Voorbeelde daarvan is: Deut 6:4 getuig van die Enigheid van God en Deut. $32: 39$ stel dit baie dui-

2") Th. L. Haitjema, De nieuwere geschiedenis van Neerlands Kerk der Hervor-ing, 's-Gravenhage 1964, blz. 110.

21) B. J. Engelbrecht, a.w., bls. 156. 
delik dat daar niemand naas God is nie. Verder: Psalm 45:8 sê dat die God van Jesus Christus Hom gesalf het met vreugdeolie bó sy metgeselle (Vgl. Jes. 61:1 en Hebr. 1:9). Volgens Luk. 2:52 het Jesus toegeneem in wysheid en genade by God en die mense. Joh. 14:28 sê dat Jesus na die Vader gaan omdat die Vader groter is as Hy. Hand. 2:36 weer sê dat God Jesus tot Here en Christus gemaak het. En Fil. 2:6 stel duidelik dat die Vader Jesus verhoog en aan Hom 'n heerlike naam gegee het wat bo elke naam is. ( Vgl. verder ook Spreuke 8:22; Mark. 13:32; I Kor. 15:24-28; Joh. 13:21; Hebr. 1:4; ens. ens.).

\section{(3) Die Ooreenkoms tussen die Christologie van die Jehova Getuies en die leer van Arius.}

Die vraag is nou: Vereenselwig die Jehova Getuies hulleself met Arius en kan ons hulle Christologie in verband bring met die leer van hierdie ketter? Die antwoord op hierdie vraag is ondubbelsinnig: $\mathrm{Ja} ! \mathrm{Want}$ in verband met die leer van die Drie-eenheid sê die Jehova Getuies die volgende :-

Die Geloofsbelydenis van Nicea wat die drieëenheid gesteun het . . . is deur die swaard van die staat afgedwing. Dit word egter nie afgedwing deur die ,swaard van die gees, dit is, die woord van God" nie. (Efesiërs 6:17, C.B.; Dy) Arius, wat die „swaard van die gees" gehanteer het om te bewys dat die drieënheid nie Skriftuurlik of Christelik was nie, is verban, en die keiser het vir Athanasius party gekies. ${ }^{23}$ ).

In die oë van die Jehova Getuies was Arius dus die verdediger van die suiwer Bybelse waarheid en vereenselwig hulle hulleself dus geheel en al met hom. Uit hulle Christologie - soos reeds gestel in Hoofstuk IV - is dit dan ook baie duidelik dat hulle dwaling in die meeste opsigte identies is met dié van Arius.

Ons het reeds gesien dat Arius se leer beheers word deur die gedagte dat God Eén is. Alleen die Vader is die Een, Enige God en alleen $\mathrm{Hy}$ is ewig en ongebore. By die Jehova Getuies vind ons presies dieselfde opvatting :-

Jehova is God en, as sulks, het hy nooit 'n begin gehad nie. . . Jehova regeer vir ewig oor die hele ruimte van die heelal. Hy is alle eer en heerlikheid werd, daar hy ewig

2") G. C. van Niftrik, a.w., blz 149 .

2:) Wat het Godsdiens vir die Mensdom gedoen? bls. 245. 
en onsterflik is, is hy, in hierdie sin, die enigste Wese . .

Daar was dus 'n tyd toe Jehova heeltemal alleen in die ruim. te van die heelal was. ${ }^{24}$ ).

Ook die uiteensetting van Hoofstuk II oor Jehova God wat Sy Kabód, Sy heerlikheid aan geen ander gee nie, spreek hier geen onduidelike taal nie.

Ten opsigte van die pre-eksistensie van Christus stel Arius duidelik dat almal behalwe God die Vader gennētos en genētos (= gebore en geword) is, d.w.s. dat ook die Seun - al is Hy monogenēs, geskape is en dus aan God die Vader gesubordineer is. Uit die Christologiese gedeelte het ons reeds gesien dat die Seun ook by die Jehova Getuies 'n skepsel is, geskape deur Jehova God as 'n magtige, geestesskepsel (Vgl. Openb. 3:14; Kol. 1:15 - soos deur hulle vertaal én verstaan). Hoewel Hy die Eniggeborene (monogenēs) was, was Hy tog baie duidelik aan die Vader gesubordineer. Hierdie subordinatianisme van die Seun aan die Vader word konsekwent deur die Jehova G :tuies gehandhaaf en spreek ook duidelik uit die volgende :-

Voordat hy na die aarde toe gekom het, het hierdie eniggebore Seun van God homself nie die gelyke van Jehova God geag nie; hy het nie beskou dat hy ,gelyk in krag en heerlikheid" aan die Almagtige God is nie; hy het nie die handelswyse van die Duiwel gevolg en 'n sameswering gesmee en planne gemaak om homself soos of gelyk aan die Allerhoogste God te maak en om God te beroof of om wederregtelik Gods plek in besit te neem nie. Inteendeel het hy sy onderhorigheid aan God as sy Meerdere getoon deur homself onder God se almagtige hand te verneder, selfs tot in die allerergste mate wat beteken tot 'n allerskandelikste dood. ${ }^{25}$ ).

Hierdie opvatting word dan skriftuurlik gegrond op Fil. 2:5-8 wat as volg vertaal word: „Christus Jesus, wat, alhoewel hy in die gestalte (of : gedaante) van God was, nie 'n verdringing bedink het om soos God te wees nie (of : nie roof bedink het om wederregtelik met God gelyk te wees nie), maar homself ontledig het deur die gestalte van 'n dienskneg aan te neem . . . " (Emphatic Diaglott). ${ }^{26}$ ).

In sy pre-eksistensie was die Seun van God dus volgens

21) Laat God Waaragtig Wees, bls. 24 en 25.

25) Laat God Waaragtig Wees, bls. 36 .

26) Vgl. Laat God Waaragtig Wees, bls. 36 en 86 . 
die Jehova Getuies nie homo-ousios met die Vader nie, en het Hy ook nie van ewigheid af bestaan nie, maar was Sy Status dié van ondergeskiktheid (subordinasie) aan die Vader. Hy was wel goddelik, maar nie Gód nie. En hierdie goddelikheid was van so 'n aard en het soveel mag ingesluit dat $\mathrm{Hy}$ die Status van Skeppingsmiddelaar beklee het - 'n opvatting wat netso ook by Arius voorgekom het.

By Sy menswording het hierdie geestelike, skepsel- Seun van Jehova God Homself volkome ontledig (Vlgs. die Jehova Getuies) van al Sy geestelike eienskappe en heerlikheid wat Hy by Sy Vader gehad het, en 'n blote mens, hoewel volmaak, geword :-

A divine miracle occured when Jesus was „made flesh". He was not an incarnation in flesh, but was flesh, a human Son of God, a perfect man, no longer a spirit, although having a spiritual or heavenly past and background. That the heavenly Word of God divested himself of everything as a godlike spirit except his lifeforce and that he lowered himself to become no more than a perfect man, his inspired apostle bears witness, .... (Fil. 2:5-8). ${ }^{27}$ ).

Dit is weereens in ooreenstemming met die opvatting van die Arianisme wat die waaragtige menslikheid van Jesus ten volle erken.

As mens het Jesus op etiese vlak toegeneem en gegroei in wysheid, kennis en guns by God, en die volk (Luk. 2:52). Deur absolute gehoorsaamheid aan die wil van Sy Vader het Hy sodanige voortgang gemaak dat Hy op dertigjarige ouderdom Homself aan Jehova kon toewy deur die doop van Johannes te ondergaan. Om Sy instemming daarmee te betoon het Jehova God deur middel van Sy heilige gees Jesus weer tot geestelike Seun verwek. As Professor Engelbrecht oor die opvatting van Arius sê : „Jesus Christus het voortgang (prokopē) in sedelike sin gemaak (Arius dink bv. aan Luk. 2:52) . . . . " dan is die ooreenkoms tussen die opvattings van beide groepe baie duidelik. In bogenoemde saak gaan dit beslis om verdienste aan die kant van Jesus en 'n beloning deur Jehova God vir sy getroue wilsgehoorsaamheid. In die wese van die saak is dit dus 'n adoptiaanse Christologie, want Jesus het volgens die

${ }^{2 i)}$,The Kingdom is at Hand", p. 49.

2) Die volle beloëning vir Sy getrouheid het $\mathrm{Hy}$ egter eers met Sy verhoging ontvang, toe $\mathrm{Hy}$ deur Jehova verhoog is, hoër as in Sy preeksistente staat. 
Jehova Getuies Homself só volkome ontledig by Sy menswording dat Hy 'n blote mens geword het en is $\mathrm{Hy}$ by $\mathrm{Sy}$ doop van 'n menslike Seun tot 'n geestelike Seun aangeneem (=opgewek, verwek), op grond van Sy getrouheid. ${ }^{2 *}$ ).

In die Jehova Getuies se opvatting oor die menswording, sterwe en opstanding van Jesus Christus vind ons 'n sterk docetiese trek. Enersyds erken hulle dat die Seun van God werklik mens geword het, ja eintlik vlees was; andersyds leer hulle dat Hy dit nie waaragtig en werklik aangeneem het nie, omdat Hy Sy menslike liggaam, dus Sy vlees in die dood afgelê het. Jesus is uit die dode opgewek as 'n verheerlikte, geestelike skepsel en as sodanig kon Hy eintlik met die aardse, die vlees niks te doen hê nie. ${ }^{29}$ ).

Ten opsigte van Christus se posteksistente verhoging het Arius 'n duidelike adoptiaanse Christologie verkondig, want Jesus Christus wat nie die natuurlike, wesenlike Seun van God was nie, is na Sy volbragte heilswerk tot Seun van God aangeneem en tot goddelike status of rang verhoog - hoewel nog gesubordineer aan die Vader. Hierdie verhoging tot goddelike status was dus eintlik 'n beloning van die kant van God die Vader vir Jesus se absolute wilsgehoorsaamheid.

Hierdie selfde adoptiaanse gedagstruktuur en gedagteinhoud vind ons weereens terug in die Christologie van die Jehova Getuies. Jesus Christus het na Sy hemelvaart die waarde van Sy menslike offer voor Jehova God gelê en as beloning daarvoor het Jehova Jesus verhoog, self nog hoër as voor Sy menswording. Die Jehova Getuies stel hierdie saak onomwonde in die volgende woorde :-

Omdat hy hierdie gedragslyn gevolg het, het dit Jesus sy aardse lewe gekos, op 'n allerskandelikste manier. Nogtans het dit Jehova se soewereiniteit oor die heelal geregverdig en het dit vir Jesus 'n plek in die heelal verwerf hoër (vetdruk J.H.B.) as wat hy tevore gehad het, ondergeskik alleen aan die van die Allerhoogste God self. ${ }^{\text {an }}$ ).

29) Hoe hierdie hele weg van die Seun van God in werklikheid verstaan moet word is nie duidelik nie. Want $\mathrm{Hy}$ het die volgende stadia deurgemaak :

1. 'n Geestelike skedsel in die hemel.

2. 'n Blote, hoewel volmaakte. mens.

3. 'n Blote mens én 'n geestelike Seun na Sy doop.

4. 'n Verheerlikte geestelike skepsel wat Sy mensheid volkome afgelê het.

30) ,.Dit Beteken die Ewige Lewe", Watchtower Bible and Tract Societv Inc.. International Bilbe Students' Association, Brooklyn, New York 1953 , bls. 186 . 
En :

.... dat Jesus in gehoorsaamheid aan Gods wil vrywillig sy lewe as losprys afgelê het, en as 'n beloning vir getrouheid het hy die reg gehad om weer die lewe aan te neem uit die hande van sy Vader deurdat Hy hom opwek. ${ }^{31}$ )

As Skriftuurlike bewysplaas word Fil. 2:8-11 aangahaal en as volg vertaal: „Toe hy homself in gedaante as 'n mens vind, het hy homself verneder en gehoorsaam geword tot sover as die dood, ja, die dood aan 'n folterpaal. Juis om hierdie rede het God hom ook tot 'n hoëre posisie verhef en goedgunstelik aan hom die naam gegee wat bo elke ander naam is, ..."

\section{(Fil. 2:8-11 en I Petrus 3:22 N.W.) ${ }^{32}$ ).}

Die Adoptianisme én Subordinarianisme spreek ondubbelsinnig uit bostaande aanhaling. Die status of posisie van die posteksistente Christus is dus hoër as Sy status in Sy preeksistensie, maar dit is nog nie gelyk aan Jehova God se status nie. Hoewel Hy tot Hoof van Jehova se hoof organisasie oor die ganse heelal gemaak is, bly $\mathrm{Hy}$ gesubordineer aan die Vader.

Netsoos by Arius, die Sociniane, die Groninger teoloë en talle moderne teoloë, geld Jesus vir die Jehova Getuies ook as die ware voorbeeld. Deur die ontkenning van die volle Godheid van Christus, moet hulle Hom noodwendig sien as een wat op dieselfde vlak gestaan het as ons mense, wat alleen maar vir ons die weg voorberei het en wat ons as voorbeeld kan navolg. Die opvatting dat Jesus as menslike Seun absolute gehoorsaamheid aan die Vader betoon het, dwing hulle ook om van verdienste en beloning te spreek ten opsigte van die verhoging van Christus en gevolglik ook van verdienste en beloning vir elke gelowige wat sy getrouheid bewys deur Christus se voorbeeld na te volg. Hierdie hele opvatting is weereens gewortel in die Jehova Getuies se optimistiese mensbeskouing.

Die mens het nie werklik God nodig om hom te verlos nie, maar alleen 'n goddelike figuur, wat homself ontledig het en as méns vir ons 'n voorbeeld gestel het.

Dit is nodig om deur middel van enkele aanhalings die Jehova Getuies self aan die woord te stel, sodat ons uit hulle eie mond kan verneem dat Jesus in werklikheid vir hulle net

31) Laat God Waaragtig Wees, bls. 91.

32) „Dit Beteken die Ewige Lewe”, bls. 186 . 
'n voorbeeld is en dat die gelowige eintlik sy saligheid moet verdien :-

To get the benefits of Jesus' human sacrifice, the one who at last attains the heavenly kingdom must believe in him, not alone as Redeemer but also as the true Example to follow toward gaining the Kingdom. ${ }^{33}$ ).

Jesus himself, in order to gain the Kingdom, did not stay at Nazareth . . . Being maturely perfect at thirty years of age, he then consecrated himself totally to God's service and left behind his carpentry. Such consecration he symbolized openly by being baptized in water

Netso moet ook elke gelowige homself aan Jehova God konsekreer :-

Out of regard for this act of faith and obedience Jehova justifies such consecrating one by the application to him of the merit of the Redeemer. Then God accepts the con secration. ${ }^{34}$ ).

Verder sê die Jehova Getuies :-

Dit is hierdie voortreflike voorbeeld wat Jehova se getuies vandag probeer navolg. Hulle glo vas, net soos Jesus self geglo het, dat hulle oortuigings waar is en dat God hulle gebruik om sy koninkryksboodskap te verkondig.

En :

Watter voortreflike voordele is al verkry deur die vriendelike, bedagsame gesindheid van Jesus Christus na te doen! ${ }^{35}$ ).

Die gelowiges moet hulle onkreukbaarheid (= integriteit) teenoor Jehova God bewys :-

Dit was so met Christus. Alhoewel hy 'n smadelike dood onder die hande van Satan se agente gesterf het, was Satan nie in staat om deur hom te bewys dat dit nie vir menslike skepsels moontlik was om onder enige toestand wat die Duiwel kon bring hulle onkreukbaarheid teenoor God te handhaaf nie. ${ }^{36}$ ).

3:) „The Kingdom is at Hand", p. 285

34) "The Kingdom is at Hand", p. 286 and 287.

3.5) Ontwaak! (Spesiale Uitgawe) 8 Oktober 1965, bls. 16 en 18

3i) Laat God Waaragtig Wees bls. 51 . 
Maar die Jehova Getuies gaan nog baie verder as hulle beweer :-

It is solely by taking the course that "the King of Kings" took and sharing in his sufferings and his manner of death that those called to the heavenly kingdom have any hope to have a part in his resurrection. ${ }^{3 i}$ ).

En :

Alleeen deur hom na te doen en aan sy beeld gelykvormig gemaak te word in getrouheid onder lyding en selfs tot die dood toe, kan enige een in die hemesle koninkryk en die voorregte van die Abrahamiese verbond ingaan. ${ }^{38}$ ).

Uit bogenoemde aanhalings is die optimistiese mensebeskouing van die Jehova Getuies baie duidelik. Ook dui dit die ontsettende gemis in die Christologie van die Jehova Getuies onweerspreekbaar aan, $\mathrm{nl}$. die ontbreking van 'n Verlosser tegelyk waaragtig Gód én waaragtig méns is.

iT) ,,The Kingdom is at Hand" p. 301.

*) Ontwaak!, Maart 1965, bls. 24. 


\section{DIE AFWYSING VAN DIE CHRISTOLOGIE VAN DIE JEHOVA SE GETUIES}

\section{(A) INLEIDING OPMERKINGS.}

Die taak om die Christologie van die Jehova Getuies volledig in al sy besonderhede op grond van die Heilige Skrif af te wys, kan nie in die bestek van hierdie studie volbring word nie. Omdat dit sig oor so 'n wye veld uitstrek, is daarvoor in werklikheid 'n afsonderlike studie nodig. Dit is egter van wesenlike belang dat ons op enkele van die belangrikste aspekte sal ingaan en die suiwer Bybelse waarheid en leer ten opsigte van Christus sal stel teenoor die halwe waarhede en valse opvattings van die Jehova Getuies. $E n$ in hierdie verband is die essensiële en allerbelangrikste taak om aan te toon dat ons die volle Godheid van Jesus Christus erken en bely, - nie omdat dit ,'n uitvindsel van mense" of ,'n leerstelling van die duiwel" is nie, maar omdat die Heilige Skrif dit leer. Só het God Homself in Sy Woord geopenbaar en só kan ons alleen maar naspreek wat God ons in Sy Woord voorgespreek het.

\section{(B) JESUS CHRISTUS, DIE DRAER VAN DIE GODDELIKE KÁBOD OF DOXA: DAAROM IS HY WAARAGTIGE GOD.}

\section{(1) Die Ou Testamentiese kābód en die Nuwe Testamentiese doxa.}

Soos ons reeds vroeër gestel het, het die Jehova Getuies op grond van Jesaja 42:8 daartoe gekom om die Godheid van Christus te ontken. Die Here God sê daar: „Ek is die Here, dit is my Naam; en my eer sal Ek aan geen ander gee, of ook my lof aan die gesnede beelde". Vgl. ook Jesaja 48:11. Dic verband waarin bogenoemde teks staan, is van groot belang. Jes. 42:1-7 handel oor die Kneg van die Here (Ebed Jahwe) in wie God 'n welbehae het. Op Hom rus die Gees van die Here en Hy sal die reg na die nasies uitbring. In hierdie perikoop gaan dit dus om die universele verlossing en bevryding déúr die Kneg van die Here. Die Kneg sal die geknakte riet nie verbreek en die dowwe lamppit nie uitblus nie.

Jes. 42:8-17 weer handel oor die verlossing en bevryding wat déúr die Here God sélf bewerk sal word. Die verlossing word dus enersyds aan die Kneg toegeskryf en andersyds aan God sélf. Daar word eintlik nie 'n onderskeid gemaak nie, want die Kneg word gegee ,om blindè oë te open; om ge- 
vangenes uit die kerker uit te lei, uit die gevangenis diegene wat in die duisternis sit" (vers 7) en die Here God sê self :

„En Ek sal blindes lei op 'n weg wat hulle nie ken nie, hulle laat loop op paaie wat vir hulle onbekend is; Ek sal die duisternis lig maak voor hulle uit en die hobbelagtig? plekke gelyktes ...." (vers 16).

Uit die verband is dit dus baie duidelik dat dit in Jes. 42:8 gaan om die verlossing van die volk deur die Here God (Hyself of Sy Kneg) en nie deur hulle afgode nie. Aan Hom alleen moet die eer daarvoor toekom en nie aan die afgode of die gesnede beelde nie. Trouens hierdie antitese tussen God en die afgode word eksplisiet in Jes. 42:8 gestel. Hy is alléén God.

Die woord wat vir ons doeleindes die kern vorm in hierdie teks is kăbôd, wat gewoonlik vertaal word met eer, heerlikheid. In die oorspronklike beteken dit: dit wat gewig besit, rykdom; reputasie, eer, onderskeiding; glorie, heerlikheid.

"The fundamental idea expressed by the root kbd is that of weightiness. Kabod designates whatever had weight. .... Since anything weighty inspires respect and honour kabod not only denotes the obvious objective reality but the feeling which is experienced towards what inspires respect. This double meaning is particularly evoked where the glory of God is concerned. . . . This glory is what God possesses in his own right, it is a kind of totality of qualities which make up his divine power; it has close affinity with the holiness which is of the nature of deity and it is a visible extension for the purpose of manifesting holiness to men. ${ }^{1}$ ).

Die kābôd is dan eintlik die goddelike ligglans in Sy verskyning, die krag van Sy self-manifestasie, die konkrete uitdrukking van die heerlikheid van Sy Wese. By die profeet Esegiël is die kăbôd selfs identies met God self :

Ezekiel moves along the line which starts from Isaiah chapter 6 where the glory appears as the normal expression of the divine presence ... According to Ezekiel the kabod is not merely the manifestation of God in concrete form, it is identical with him; that is why, as in certain passages of Genesis where the angel of Jahweh and Jahweh

1) Edmond. Jacob, Theology of the Old Testament, London 1964, p. 79. 
are almost confused, God and the kabod are interchangeable, e.g. Ez. 9, where in verse 3 kabod is the subject, but in verse 4 the subject is Jahweh. ${ }^{2}$ ).

Die Here God gee dus Sy kābőd, Sy goddelike heerlikheid aan geen ander nie; Hy deel dit met geen afgod nie. Hy is dus die alleenbesitter van die kābôd, van die goddelike heerlikheid, van die goddelike Wese. Daarop grond die Jehova Getuies hulle ontkenning van die volle Godheid van Christus. Maar die omgekeerde is netso waar en geldig: As daar Een is wat die kābôd besit saam met God, dus ook draer is van die goddelike heerlikheid, van die goddelike Wese, dan is daardie Een ook ten volle en waaragtig Gód - dan moet ook daardie Een se volle Godheid erken word. Juis dít erken en bely die Kerk op grond van die getuienis van die Heilige Skrif.

Die ekwiwalent van kābôd in die Septuaginta en in die Nuwə Testament is doxa. Doxa beteken in alle buite-Bybelse Grieks : dit wat iemand dink, 'n opinie; en verder: roem, aansien, eer. In die Nuwe Testament kom die betekenis van „opinie" gladnie voor nie (dit is deur ander terme vervang bv. deur gnómē, ens.) In die sin van ,roem, eer", vind ons dit nog in die Nuwe Testament (vgl. Luk. 14:10; I Kor. 11:15, ens.) In die Nuwe Testament egter, tref ons 'n totaal nuwe betekenis aan waarvoor daar in die buite-Bybelse Grieks byna geen analogie is nie, $\mathrm{nl}$. in die betekenis van goddelike en hemelse skittering (luister), goddelike ligglans; die hoogheid en majesteit van God; en selfs die Wese, van God.

Die word doxa het hierdie besondere betekenis in die Nuwe Testament gekry via die Septuaginta onder invloed van die Ou Testamentiese kābôd:

Das Septuagintawort doxa hat seine Prägung völlig dadurch erhalten, dass es Wiedergabe von kābôd wurde : die in kăbôd liegenden Bedeutungen kehren in ihm wieder, die in kābôd nicht vorhandenen Bedeutungen des griechischen doxa - Begriffes fehlen in Septuagintawort. Es is mit kābôd indentisch geworden. ${ }^{3}$ ).

En verder:

Dabei sind in N.T., genau wie im Septuagintawort, die Ubergange der Bedeutungen: göttliche Ehre göttliche Pracht,

2) Edmond Jacob, 1.c., p.81. 
göttlicher Glanz oft fliessend und nur künstlich gegeneinander abzugrensen. Inhaltlich jedenfalls liegt immer eine und dieselbe Aussage über die göttliche Wesensart vor, nur dass die Sichbarkeit bald gar nicht oder wenig, bald kräftig betont ist ..." ").

Die Nuwe Testament het egter 'n baie belangrike nuwe element in die gebruik van die woord. Doxa word nl. in sy spesifiek Nuwe Testamentiese betekenis nie net gebruik in verband met God, die Vader (soos die woord kābôd in die Ou Testament) nie, maar ook in verband met Jesus Christus. Dit dien dan om die besondere en enige verhouding van Christus tot God, die Vader, tot uitdrukking te bring. Christus is die draer van die goddelike doxa, net soos God self, en daarom is Hy Sélf ook waaragtig God.

Dagegen tut die nt. liche Gräzität ihrerseits einen entscheidenden Schritt, indem sie das Wort das Träger der Gottesaussage geworden war, sugleich zum Träger der Christusaussage macht. Das Verhältnis kann auf mancherlei Weise ausgedrückt werden und spiegelt dabei in der Anwendung der Vokabel die ganze Bewegtheit des Gott/Christus-Verhältnisses. Christi Auferstehung ist gewirkt dia tēs doxēs tou patros R6, 4. Der Erhöhte anelēfthē en doxēi I Tim. 3, 16. Stephanus sieht die doxa Gottes und den Erhöhten in ihren Sphäre Ag. 7, $55 \ldots 5$ ).

Om hierdie saak egter nog beter te verstaan en alvorens ons nog verdere opmerkings daaroor maak, is dit noodsaaklik om eers te let op die eksegese van Calvyn ten opsigte van Fil. 2:6.

\section{(2) Calvyn se Eksegese van Fil. 2:6.}

Die verklaring deur Calvyn van hierdie absoluut-essensiële Christologiese teks, is vir ons in hierdie verband van die allergrootste belang. In sy eksegese het Calvyn op wetenskaplike wyse aangetoon dat Fil. 2:6 baie duidelik die volle Godheid van Christus impliseer en aandui.

Die kernwoord in hierdie teks is morfe $=$ vorm, gestalte, gedaante. In sy verklaring van morfē volg Calvyn dieselfde gedagtegang as wat ons by die verklaring van die Ou Testa-

3) Gerhard Kittel, Theologisches Wörterbuch zum Neuen Testanent, Stuttgart 1953, Band II. S.245 und 246.

1) Gerhard Kittel. a.a.O., S 251.

i) Gerhard Kittel, a.a.0., S. 251. 
mentiese kābôd aangetoon het. Soos kābôd die goddelike ligglans is by God se verskyning en dus uitdrukking is van Sy Wese, só verklaar Calvyn morfē op dieselfde wyse :

The form of God means here His majesty. For as a man is known by the appearance of his form, so the majesty which shines forth in God is His figure. Or if you prefer a more apt similitude, the form of a king is the equipage and magnificence which shows him to be a king, his sceptre, his crown, his robe, his attendants, his judgementthrone, and other emblems of royalty ... Christ, then, before the creation of the world, was in the form of God, because from the beginning $\mathrm{He}$ had His glory with the Father, as He says in John 17:5. ").

En verder :

Form means figure or appearance, as they commonly say. This, too, I readily grant; but will there be found, apart from God, such a form, that is neither false nor forged? As then, God is known by His powers, and His works are witnesses of His eternal divinity (Rom. 1:20), so Christ's divine essence is rightly proved from Christ's majesty. which He possessed equally with the Father before he humbled Himself. ').

Vir Calvyn beteken God se morfē = gedaante, gestalte, dus Sy majesteit en glorie. Calvyn gee wel toe dat morfē nie direk met ousia $=$ substantia $=$ Wese vertaal $k a n$ word nie, maar dat dit tog baie duidelik ousia $=$ Wese impliseer. Want soos ons kābôd = heerlikheid vroeër verklaar het nl. dat dit uitdrukking is van die Wese van God, so is morfe $=$ gestalte, gedaante $=$ majesteit en glorie, vir Calvyn die uitdrukking van God se Wese. Sy majesteit en glorie wat Hy besit, wat Hy het, is uitdrukking van dit wat Hy besit, wat Hy het, is uitdrukking van dit wat $\mathrm{Hy}$ is. As Christus dan voor Sy menswording deelgehad het aan hierdie majesteit en glorie van God (hos en morfē theoú huparchón), dan is dit ook uitdrukking van Sy Wese, dus van Sy volle Godheid.

Ouch harpagmon hēgēsato tò eina isa theou. Hierdie teksgedeelte betrek Calvyn op Jesus Christus se vernedering in Sy

6) T. H. L. Parker, Calvin's Commentaries, The Enirtles of Paul th? annatle to the Galatians, Ephesians, Philippians and Coloss ans, Fdinhurgh, 1965. p. 247.

¡) T. H. L. Parker, Calvin's Commentaries, l.c. p. 248. 
menswording. Hy wat in die gestalte van God was, wat deelgehad het aan die goddelike majesteit en glorie en wat dus Sélf ook Gód was, het die volle reg gehad om Homself as sódanig onder die mense te bewys.

There would have been no wrong done even if $\mathrm{He}$ had appeared in His equality with God. For when he says, he would not have thought, it is as though he had said, ,He knew, indeed, that this was lawful and right for him that we might know that His abasement was voluntary, not of necessity. ${ }^{\circ}$ ).

Dát Hy Homself nie só geopenbaar, aan die mense vertoon het, soos wat Hy inderdaad en in werklikheid was nie, is dus aanduiding van Sy absoluut vrywillige vernedering.

Calvyn sê verder oor hierdie teksgedeelte:

I acknowledge, certainly, that Paul does not mention here Christ's divine essence; but it does not follow from this, that the passage is not sufficient to overthrow the impiety of the Arians, who pretended that Christ was a created God, and inferior to the Father and denied that He was consubstantial. For where can there be equality with God without robbery except only in the essence of God? ${ }^{9}$ ).

In hierdie opsig vereenselwig ons ons volkome met Calvyn se standpunt en is dit ook óns standpunt ten opsigte van die Christologie van die Jehova Getuies.

Calvyn is dus ten volle oortuig daarvan dat Fil. 2:6 die Godheid van Jesus Christus impliseer. $\mathrm{Hy}$ is waaragtige en ewige God, van dieselfde Wese as die Vader. Daarom kon Calvyn ten slotte oor hierdie teks opmerk:

As to myself, at least, not all the devils would wrest this passage from me, inasmuch as there is in God a most solid, argument from His glory to His essence, which two things are inseparable. $\left.{ }^{11}\right)$.

(3) VERDERE OPMERKINGS OOR DIE DOXA VAN JESUS CHRISTUS : VERBORGE DOXA.

Soos reeds vroeër opgemerk, gebruik die Nuwe Testament die woord doxa nie net vir God, die Vader, nie, maar ook vir

*) T. H. L. Parker, Calvin's Commentaries, 1.c., p. 247.

9) T. H. L. Parker, Calvin's Commentaries, l.c., p. 247 and 248.

iii) T. H. L. Parker, Calvin's Commentaries, I.c., p. 248. 
Jesus Christus. So sê Jesus bv. in Joh. 17:5 ,En nou, Vader, verheerlik My by Uself met die heerlikheid wat Ek by $U$ gehad het voordat die wêreld was", In die meeste gevalle het dit egter betrekking op die verheerliking van die opgestane Heer (vgl. bv. I Petrus 1:11; I Petrus 4:11; Hebr. 13:21; I Kor. 2:8; Jak. 2:1; Openb. 5:12 en 13, ens.) Die woord word selde gebruik ten opsigte van Jesus tydens Sy aardse lewe in die vlees. (In die Sinoptiese Evangelies wel in verband met Sy wederkoms, bv. Mark. 13:26 en Matt. 25:31 en in verband met Sy geboorte Luk. 2:9 en Sy verheerliking op die berg Luk. 9:32).

In die Evangelie van Johannes vind ons egter meer verwysings na die doxa van die aardse Jesus. Dit hang nóu daarmee saam dat die duidelike neiging van die Johannes Evangelie is om die aardse lewe van Jesus te beskrywe vanuit die gesigspunt van die verhoging, die verheerliking van die opgestane Heer. Maar dit staan dan ook altyd in verband met die geloof - dit moet gegló word (vgl. Joh. 2:11; 11:40, ens.).

Ten opsigte van Joh. 1:14 stel Gerhard Kittel dan :

Auch das etheasametha tēn doxan autou ist ja nicht eine allgemeine Aussage in der dritten, sondern die spezielle Aussage des Jüngers in der ersten Person (vgl. tois pisteuousin 1, 12). Es ist also auch bei Johannes keineswegs an und für sich an Jesus die doxa sichtbar, sowenig wie bei den Synoptikern. Das Geheimnis seiner Person muss hier wie dort ,enthüllt' Mt. 16, 17 und geglaubt werden. ${ }^{11}$ ).

Hoewel Sy heerlikheid dus in die meeste gevalle alleen in en deur die geloof gesien is, kon Oscar Cullmann nogtans ten opsigte van Joh. 1:14 tereg opmerk:

Auf jeden Fall scheinen die Schlussverse des Prologs (John 1, 14-18) unmittelbar auf den Menschensohngedanken hinzuweisen, wenn es da heisst : Wir schauten seine Herrlichkeit (doxa), eine Herrlichkeit, wie sie der eingeborene Sohn vom Vater hat". Dieser Vers erinnert ganz an die paulinischen Ausführungen über Jesus als Ebenbild Gottes. Weil Jesus Christus das Ebenbild Gottes ist, sind nun auch wir imstande, Gott selbst zu kennen; es ist Gottes eigene Herrlichkeit, die wir sehen, wenn wir Christus sehen : „Nie-

11) Gerhard Kittel, a.a.O., S. 252. 
mand hat Gott je gesehen; der eingeborene Sohn hat Kunde gebracht". ${ }^{21}$ ).

Uit hierdie teks spreek die goddelike heerlikheid van Jesus Christus dus ook ondubbelsinnig.

Die goddelike doxa, heerlikheid van Christus het egter eers in en deur Sy opstanding uit die dode baie duidelik aan die lig getree. Tóé eers kon Sy dissipels werklik Sy heerlikheid sien, dit aanskou. Die vraag kom nou op: Hoe moet ons hierdie saak van die goddelike doxa van Jesus Christus werklik verstaan? Want daar is sprake in die Skrif van Christus se doxa in Sy preeksistente staat by God die Vader, van Sy doxa tydens Sy aardse lewe (wat alleen deur die geloof gesien kon word) en van Sy doxa na Sy opstanding en verheerliking? Die antwoord op hierdie vraag is hierin geleë dat Jesus se heerlikheid tydens Sy aardse lewe verborge heerlikheid was. Hy het Sy goddelike heerlikheid onder die swakke, menslike vlees verberg, bedek. Dr. G. C. van Niftrik stel dat die heerlikheid van Jesus wat soms wel tydens Sy aardse lewe gesien is déúrbrekende tekens was van Sy verborge heerlikheid. Hy verklaar die saak dan verder só :

Maar door die schamele omhulling (geen gestalte, geen luister, Jes. 53:2) breken telkens goddelijke heerlijkheid en mach heen - als een flits - een enkel ogenblik. Als men Hem in Nazareth van de steilte wil werpen, gaat Hij midden tussen hen door en vertrekt, en allen moeten Hem loslaten (Luc. 4:30). Wat is dat voor een geheimzinnig openbaarworden van zijn verborgen wezen? In Getsémane moet de bende, die Hem gevangen wil nemen, huns ondanks voor Hom knielen (Joh. 18:3 vv.). Op die berg der verheerlijking verandert zijn gedaante voor hun ogen (Matth. 17:2). ${ }^{13}$ ).

Hierdie selfde opvatting vind ons by. Calvyn ten opsigte van die Seun se kenósis, Sy ontlediging (Fil. 2:7). Die Seun van God het met Sy menswording nie Sy goddelike heerlikheid, Sy Godheid afgelê, Homself daarvan ontledig (soos bv. deur die Jehova Getuies geleer word) nie, maar $\mathrm{Hy}$ het dit onder die menslike vlees verberg:

Christ, indeed, could not renounce His divinity, but $\mathrm{He}$ kept it concealed for a time, that under the weakness of the flesh it might not be seen. Hence $\mathrm{He}$ laid aside His

12) Oscar Cullmann, Die Christologie des Neuen Testament, Tübingen 1963, S. 192.

13) G. C. van Niftrik, a.w., blz. 136. 
glory in the view of men, not by lessening, but by concealing (supprimendo) it. ${ }^{14}$ ).

Ook Karl Barth verklaar dit op dieselfde wyse in sy eksegese van Fil. 2:7:

In souveräner göttlicher Freiheit legt er die Gottesgestalt, alle Erkennbarkeit seines Seins ab - das heisst ekenósen also nicht nur, er verbarg es. Er begibt sich dahin wo nur er selbst sich so kennt, wie der Vater ihn kennt .... Das heisst : er ist so da, dass er aller direkten, unmittelbaren z.B. aller historisch - psychologischen Betrachtung nicht das Bild seines eigentlichen, ursprünglichen, göttlichen, sondern schlechterdings das Bild eines menschlichen Seins darbietet... Ist er nich Gott gleich ? Er ist es. Aber wo sehen wir denn etwas davon? Wo ist der Strahlenkranz seiner Gottheit? Wie einen Vorhang bedeckt eben die humilitas carnis die divina majestas (die Niedrigkeit des Fleisches die göttliche Hoheit), sagt Calvin. Sie tut es auf der ganzen Linie. ${ }^{15}$ ).

Jesus Christus het dus Sy goddelike heerlikheid, Sy volle Godheid te alle tye behou. Dit was alleen vir 'n tyd lank onder die menslike vlees verberg, hoewel dit by sekere geleenthede met goddelike krag déúr die omhulling van die menslike vlees déúrgebreek het. Hy was dus op geen stadium minder Gód as voor Sy menswording nie. Sy status was dié van volle Godheid, ook in Sy menswording en menslike bestaan.

\section{(4) NOG ENKELE BEWYSPLASE VIR DIE VOLLE GODHEID VAN JESUS CHRISTUS.}

Die volle Godheid van Christus word ook nog uit ander Skrifgedeeltes betuig. Hoewel ons nie volledig daarop kan ingaan nie, is dit tog noodsaaklik om enkele opmerkings oor sommige daarvan te maak. Die belangrikste is beslis Joh. 1:1. Die Jehova Getuies vertaal kai theos ēn ho logos met ,en die Woord was 'n god (of : goddelik)" op grond daarvan dat Theós sonder 'n lidwoord voorkom. Maar dit hou dan in dat die skrywer één woord in dieselfde vers in twéé verskillende betekenisse gebruik, nl. „God" en ,goddelik”. Verder is hierdie argument van die Jehova Getuies nie standhoudend nie, omdat in die Evangelie van Johannes 'n duidelike voorbeeld is

14) T. H. L. Parker. Calvin's Commentaries, 1.c. p. 248.

15) Karl Barth, Erklärung des Phillipperbrieffes, Zürich, 1947, S. 61. 
waar theos wél met die lidwoord vir Christus gebruik word, $\mathrm{nl}$. in die Thomasbelydenis in Joh. 20:28: ho kurios mou ho theas mou = my Here en my God! (vgl. ook Hebr. 1:9 - hoewel die lidwoord ook aanduiding is van die vokatief). Daarom kan Oscar Cullmann tereg hieroor opmerk:

Wir haben davon gesprochen, dass die Aussage van Joh. 1, 1 nicht abgeschwächt werden darf, als hiesse es : ,'gottlich' war der Logos". Ausserden wäre diese Erklärung in Thomasbekenttnis unmöglich. ${ }^{16}$ ).

Die wetenskaplike vertaling en eksegese van Joh. 1:1 toon dus baie duidelik die volle Godheid van Jesus Christus aan.

Verder kan ons verwys na Joh. 1:18 monogenēs theos. Hoewel dit 'n variante lesing is (die ander is monogenēs huios), is dit gesien in sy samehang met die geheel van die Johannes Evangelie tog die mees waarskynlike lesing.

Die Lesart theos ist zweifellos die bestbezeugte, wie jede kritische Textausgabe ohne weiteres erkennen lässt.

Dagegen erweist sich die Verbindung van theos mit dem Kontext, sofern sie ursprünglich ist, zwar als schwierig für das Verständis Späterer, aber durchaus nicht als unmöglich im Rahmen der übrigen Ausführungen des Johannesprologs ... Wenn dem so ist, dann entspricht es vollkommen dem johanneischen Gebrauch, dass auch niemand Gott (den Vater) je gesehen het, dass aber Gott als monogenēs ihn (sich) in dem nun folgenden Leben Jesu offenbart. ${ }^{15}$ ).

Nog 'n voorbeeld is Matt. 1:23: Emmanouēl, dit is as dit vertaal word : meth hēmón ho theos $=$ God met ons, by ons. Hy wat in Jesus Christus na ons toe gekom het, is nie ,'n god" of ,goddelik" nie, maar Hy is ho theos, Hy is God, in die volle sin van die woord. Vergelyk ook I Tim. 3:16 : „En onteenseglik, die verborgenheid van die godsaligheid is groot: God is geopenbaar in die vlees, ..." (variante lesing).

So is daar nog talle voorbeelde wat genoem kan word. (Vgl. bv. Joh. 14:9); 10:30, ens.). Maar die belangrikste is dat die getuienis van die Nuwe Testament in sy geheel Jesus Christus aan ons verkondig as Gód (wat vlees geword het), - nie as 'n halfgod naas of onder God, die Vader, nie, maar as waaragtige, ewige God, van dieselfde Wese as die Vader.

16) Oscar Cullmann, a.a.O., S. 316.

17) Oscar Cullmann, a.a.O., S. 317. 
(5) Hoe moet ons dan dié tekste verstaan wat deur die Jehova Getuies aangewend word om die ondergeskiktheid van die Seun aan die Vader te bewys?

Hierdie tekste, soos Luk. 2:52 (wat spreek oor die sedelike vooruitgang van Jesus), Joh. 14:28 (waar Christus sê dat die Vader groter is as Hy), Fil. 2:9 (wat spreek oor Christus se verhoging) en talle andere, moet in die geheel van die Nuwe Testamentiese boodskap verstaan word. Die Nuwe Testament verkondig aan ons dat Jesus Christus waaragtige en ewige Gód is, maar óók dat Hy waaragtig méns geword het. Daarom getuig die Skrif van Sy Godheid én van Sy mensheid as Jesus enersyds sê : „Ek en die Vader is een” (Joh. 10:30) en andersyds : ". . . Ek gaan na my Vader, omdat my Vader groter is as Ek"(Joh. 14:28). Laasgenoemde het Jesus bely as méns. Oscar Cullmann stel hierdie saak só:

Anderseits aber haben wir gesehen, dass es gleichzeitig von diesem Logos, der Gott ist, heisst, er sei bei Gott, Mit R. Bultmann haben wir daraus geschlossen, dass der Logos Jesus Christus doch nicht ein zweiter Gott neben Gott sein kann auch nicht eine Emanation Gottes, sondern eben Gott - aber nur insofern er sich offenbart. Nur in diesem Sinne ist der Satz von Joh. 14, 228 gemeint, dass der Vater, zu dem Jesus nach dem vollendeten Lebenswerk zurückkehrt, ,grösser ist" als er. ${ }^{18}$ ).

Waar daar dus in die Nuwe Testament sprake is van die minderheid van Jesus ten opsigte van God, die Vader, van Sy ontleding, verhoging, verheerliking, ens. moet dit op Sy mensheid betrek word. Maar dan moet ons dit altyd só verstaan, soos dit kernagtig deur Prof. B. J. Engelbrecht as volg uiteengesit word :

In sy menswording is Jesus Christus wel minder as die Vader na Sy mensheid (minor Patri secundum humanitatem) en daarom betrek die kenosis en hupsosis (ontlediging en verhoging en verheerliking) sig op Sy mensheid. Hierdie minor Patri secundum humanitatem betref Jesus se hele Middelaarspersoon, maar op so 'n wyse dat die minoritas, kenosis en hupsosis nie impliseer dat Sy wesenlike Godheid en alle wesenlike eienskappe op enige stadium die minste aangetas is nie. ${ }^{19}$ ).

18) Oscar Cullmann, a.a.O., S. 316.

19) B. J. Engelbrecht, a.w., bls. 189. 
In die Christologie van die Jehova Getuies is daar in werklikheid nog baie aspekte wat ten sterkste afgewys moet word. Al hierdie dwalings en afwykings hang ten nouste saam met hulle eintlike en groot dwaling, nl. die ontkenning van die volle Godheid van Jesus Christus. Soos reeds vroeër gestel is, kan ons in die bestek van hierdie studie nie volledig ingaan op al die verskillende aspekte nie. Tog wil ons enkeles nog kortliks aanstip :

(a) Die ontkenning deur die Jehova Getuies van die liggaamlike opstanding van Jesus Christus is beslis nie Skriftuurlik nie. Ons vind 'n sterk docetiese trek in hierdie opvatting en daarom moet ons dit op grond van die Heilige Skrif ten sterkste afwys. Die apostel Johannes het baie duidelik teen hierdie dwaling gepolemiseer toe hy gestel het: „En die Woord het vlees geword en onder ons gewoon - . ." (Joh. 1:14 - vgl. ook I Joh. 1:1-3). So het ook Paulus dit onomwonde gestel in Gal. 4:4: „Maar toe die volheid van die tyd gekom het, het God sy Seun uitgestuur, gebore uit $\mathbf{n}$ vrou, gebore onder die wet", (Vgl. hierby ook Rom. 8:3 en I Tim. 3:16). So ook die skrywer van die brief aan die Hebreërs: „Aangesien die kinders dan vlees en bloed deelagtig is, het $\mathrm{Hy}$ dit ook op dieselfde wyse deelagtig geword ..." (Hebr. 2:14). Dit is dus uit die Nuwe Testament en dan veral uit die Hebreërbrief baie duidelik dat Jesus Christus werklik die vlees aangeneem het en waaragtig mens geword het. En daarom kon $\mathrm{Hy}$ dit nie weer in die dood aflê nie, maar het Hy mét Sy mensheid liggaamlik opgestaan. Dit word betuig in die Evangelies deur die opstandingsgeskiedenisse en in nog duideliker taal deur Paulus in I Kor. 15:20 en 21 : „Maar nou, Christus is opgewek uit die dode; Hy het die eersteling geword van die wat ontslaap het. Want aangesien die dood deur ' $n$ mens is, is die opstanding van die dode ook deur 'n mens".

Die erkenning van die liggaamlike opstanding van Jesus Christus, op grond van die Heilige Skrif, is ' $n$ absolute heilsnoodsaaklikheid. Dit getuig Paulus as hy sê : ,en as Christus nie opgewek is nie, dan is julle geloof nutteloos, dan is julle nog in julle sondes"; (I Kor. 15:17). Paulus stel dit baie duidelik: "... Christus is opgewek ..." (vgl. vers 20), maar dan nie as 'n verheerlikte ,geestelike skepsel" nie, maar as die verheerlikte Godmens. Alleen dáárin is ons troos geleë én die sekere wete dat ook óns liggaamlik sal opstaan (deur 
God opgewek). Dit sny ook alle askese en veral minagting ten opsigte van die aardse lewe en -liggaam af (soos ons dit baie duidelik by die Jehova Getuies aantref.)

(b) Verder moet ons ook die Jehova Getuies se opvatting van Jesus as die groot Voorbeeld by die wortel afsny. Die Skrif getuig wel ten oorvloede dat ons Christus moet navolg en aan Sy beeld gelykvormig moet word. So stel Paulus in Fil. 2:5: "Want hierdie gesindheid moet in julle wees wat ook in Christus Jesus was". Calvyn lewer as volg daaroor kommentaar:

He now commends humility from the example of Christ to which he had before exhorted them in words. ${ }^{20}$ ).

En ten opsigte van vers 9 sê Calvyn :

This consideration, however, moves us to imitate Him the more cheerfully, when we hear that nothing is better for us than to be formed to His image. ${ }^{21}$ ).

Vergelyk verder bv. ook Matt. 11:29; Rom. 8:29; Fil. 3:10; Kol. 1:24, ens. Maar hierdie Skrifgedeeltes is geen gronde vir die opvatting van die Jehova Getuies nie, omdat hulle opvatting in die wese van die saak daarop neerkom dat elke mens Jesus stiptelik moet navolg om daardeur eintlik sy saligheid te verwerf; om deur sy getrouheid ' $n$ plek in die hemelse koninkryk of op die nuwe aarde te ontvang as "beloning". Maar só verkondig die Skrif Jesus as Voorbeeld beslis nie.

Alleen omdat Hy vir ons gely en gesterwe het, daarom kan en móét ons Hom navolg) - nie om ons saligheid daardeur te te verwerf nie, maar om ons dankbaarheid te bewys vir die saligheid wat ons rééds het, uit genade in Jesus Christus. Daarom is die navolging van Jesus as Voorbeeld nie die vóórwaarde vir die saligheid (soos by die Jehova Getuies) nie, maar is dit die gevolg, die vrúg van die saligheid (soos die Heilige Skrif ons dit leer). As ons dus die voorbeeld van Christus navolg, dan is dit nie uit ons eie krag nie, maar déúr die krag van Gód, die Heilige Gees. Daarom sê Paulus dan ook: "Daarom, my geliefdes, soos julle altyd gehoorsaam gewees het, nie in my teenwoordigheid alleen nie, maar baie meer nou in my afwesigheid, werk julle eie heil uit met vrees en bewing; want dit is God wat in julle werk om te wil sowel as om te werk na sy welbehae". (Fil. 2:12 en 13).

(c) Ook die koninkryksbegrip van die Jehova Getuies moet

2ii) T. H. L. Parker, Calvin's Commentaries, l.c., p. 246.

21) T. H. L. Parker, Calvin's Commentaries, 1.c., p. 250. 
as onskriftuurlik afgewys word. Die Jehova Getuies het die Koninkryk van God verabsoluteer en dit gemaak tot 'n opsigselfstaande grootheid. Christus moes nl. (vlgs. die Jehova Getuies) na Sy hemelvaart in die hemele wag vir die oprigting van die koninkryk op God se regte tyd (d.i. 1914). Tóé eers het Hy die Koningskap van God ontvang (= het Hy begin regeer oor Sy vyande).

Maar dit is nie die boodskap van die Skrif in verband met die Koninkryk nie. Die Bybelse begrip „Koninkryk” (Basileia) beteken eintlik God se Koningsheerskappy. Daarom het Jesus in die begin van Sy amptelike werksaamheid verkondig: „Bekeer julle, want die koninkryk van die hemele het naby gekom" (Matt. 4:17). In Jesus Christus Sélf het die Koningsheerskappy van God naby gekom. (Vgl. Matt. 12:28 en Luk. 11:20). Op 'n vraag van die Fariseërs oor wanneer die Koninkryk van God sal kom, het Jesus hulle geantwoord: „Die koninkryk van God kom nie met sigbare tekens nie. En hulle sal nie sê : Kyk hier ! of : Kyk daar! nie; want die koninkryk van God is binne-in julle". (Luk. 17:20 en 21). Deur die erkenning in die geloof van die Koningsheerskappy van God in die gelowige se lewe, het hy reeds deel aan die Koninkryk van God, is die Koninkryk binnein hom.

Jesus Christus het deur Sy absolute getrouheid aan die wil van Sy Vader en deur Sy lyding en sterwe nie bewys dat Hy werd is om Koning te wees in God se Koninkryk (soos die Jehova Getuies verkondig) nie, maar $\mathrm{Hy}$ het dáárdeur bewys dat Hy die Koning is; Hy hoef nie Koning te word nie, want Hy is dit van alle ewigheid af. Christus het óók nie gewag tot 1914 voordat $\mathrm{Hy}$ as Koning teen die Satan geveg en oorwin het nie, maar Hy het die oorwinning reeds op Golgota behaal. Paulus sê : Die laaste vyand wat vernietig word, is die dood" (I Kor. 15:26). Op Golgota het Jesus Christus reeds sonde en dood oorwin - dáár het Hy die angel van die dood nl. die sonde uitgetrek, vernietig (Vgl. I Kor. 15:56) - dit is deur Sy opstanding uit die dode bevestig en verseël. Tog moet dit wat op Golgota reeds in beginsel beslis is, in die laaste dag nog tot volle openbaring kom. Dan sal aan die lig kom wat reeds lankal volbring is. Daarom is dit dat die apostel Paulus ook sê: „En wanneer hierdie verganklike met onverganklikheid beklee is en hierdie sterflike met onsterflikheid beklee is, dan sal vervul word die woord wat geskrywe is : Die dood is verslind in die oorwinning. Dood, waar is jou angel? 
Doderyk, waar is jou oorwinning ?" (II Kor. 15:54 en 55). Op grond van die Heilige Skrif verwerp ons dus die verabsoluteerde wanvoorstelling van die Koninkryk van God by die Jehova Getuies as onskriftuurlik.

\section{(D) SLOTOPMERKINGS.}

Uit die voorafgaande Hoofstukke is die ontsettende gemis in die Christologie van die Jehova Getuies onmiskenbaar duidelik, nl. die gebrek aan 'n Verlosser wat tegelyk waaragtige, ewige God én waaragtige, regverdige mens is. Daarom kan ons ook tereg die vraag stel: Is hierdie opvatting van die Christologie nie ook die grondoorsaak waarom die Jehova Getuies só krampagtig die ure tel wat hulle in die arbeidsveld deurbring, die verspreiding van hulle literatuur verhaas en die getalle daarvan vergroot nie? Die tyd na die einde toe is min, daarom moet daar méér boeke versprei word, daar moet méér aankondigers in die veld wees, daar moet lánger ure aan die aankondigingswerk bestee word, daar moet méér dissipels gemaak word, ens. - want is dit nie moontlik dat hulle by die Heer se aankoms sal uitvind dat hulle nie genóég gedoen het nie ? Wáár is die waaragtige Christelike vryheid en blydskap wat rus in die sekere en vaste wete dat jou Verlósser lééf - Hy wat alles vir jou rééds gedoen het?

Daarom wil ons met alle nadruk teenoor die Jehova Getuies stel:

Jezus is geen half-god, die half-boven is, en geen schijnmens, die halfbeneden is. Hij is God en mens. Omdat $\mathrm{Hij}$ God is, kan Hij helpen, omdat Hij mens is kan Hij lijden. .... (Noordmans). ${ }^{22}$ ).

En só wil ons dan ten slotte mét die Kerk van alle eeue en sóós die Kerk van alle eeue bely:

Ons glo in een God ... En in een Heer. Jesus Christus, die eniggebore Seun van God, gebore uit die Vader voor alle eeue; (God uit God) Lig uit Lig, waaragtige God uit waaragtige God, gebore nie gemaak nie, van dieselfde wese met die Vader; deur wie alle dinge gemaak is; wat ter wille van ons, mense, en ons saligheid neergekom het uit die hemel en vlees geword het uit die Heilige Gees en die maagd Maria, en 'n mens geword het, wat ook vir ons gekruisig is onder Pontius Pilatus, gely het en begrawe is; en

22) G. C. van Niftrik, a.w. blz. 147. 
op die derde dag opgestaan het volgens die Skrifte; wat opgevaar het na die hemel, en wat sit aan die regterhand van die Vader; wat weer sal kom met heerlikheid om te oordeel die lewende en die dode, wie se ryk geen einde sal hê nie . . . ${ }^{23}$ ).

2:3) Nicaeno-Constantinopolitanum. 